\title{
Insights in animal models for translational cardiovascular research:A pharmaceutical industry perspective
}

\author{
ziyin $\mathrm{wu}^{1}$, Liang $\mathrm{Cao}^{1}$, Zeyu $\mathrm{Cao}^{1}$, Tuanjie Wang${ }^{2}$, Zhenzhong Wang ${ }^{1}$, Xin Wang ${ }^{3}$, and Wei \\ $\mathrm{Xiao}^{2}$ \\ ${ }^{1}$ State Key Laboratory of New-tech for Chinese Medicine Pharmaceutical Process \\ ${ }^{2}$ Jiangsu Kanion Pharmaceutical Co.,Ltd. \\ ${ }^{3}$ The University of Manchester
}

April 22, 2021

\begin{abstract}
The pathological mechanisms involved in Heart failure (HF) are complex and remain controversial. Caused by a variety of predisposing and exacerbating factors for HF development, the selection of animal models in current preclinical R\&D has been a major challenge. In this review, we give a comprehensive overview of different models in various species currently used in HF research, and discuss their general applicability. In addition, we summarize the preclinical research review of approved drugs for $\mathrm{HF}$, which provides theoretical and practical guidance for researchers considering preclinical studies for the treatment of $\mathrm{HF}$.
\end{abstract}

\section{Introduction}

Cardiovascular disease (CVD) is the leading cause of morbidity and mortality worldwide, of which heart failure (HF) is among the top causes of cardiovascular mortality, accounting for approximately 80000 deaths annually in the United States alone (Virani et al., 2020).

HF is defined as a complex progressive disease that is secondary to abnormal structure and function of the heart, which causes dysfunction of ventricular systolic and/or diastolic function, thus impairing the blood flow capacity of the heart under normal pressure or the ejection capacity meeting the needs of metabolic organs. The four main triggers of HF include ischemic heart disease, hypertensive heart disease, idiopathic dilated cardiomyopathy, and valvular heart disease (Dokainish et al., 2017). Besides, pathogenesis and pathological processes of HF it also involves comorbidities like obesity, type II diabetes, and chronic kidney disease. Despite such complexity of HF pathological mechanism, it is believed that myocardial remodeling, caused by chronic activation of the renin-angiotensin-aldosterone axis and the sympathetic nervous system (SNS) is the key factor in the occurrence and development of HF (Triposkiadis et al., 2009). Myocardial remodeling can initially partially compensate for cardiac function, but with the aggravation of myocardial remodeling, cardiac function gradually changes from compensatory to decompensated, with obvious symptoms and signs characterized by loss of myocytes, hypertrophy and fibrosis.

Indeed, HF therapies developed in the past decades are based on evidence-based approaches to treat HF risk factors and the implementation of treatment with angiotensin-converting enzyme (ACE) inhibitors, $\beta$-blockers, coronary vascularization, implantable cardioverter-defibrillators, and cardiac resynchronization therapies. As indicated by data from Kaiser Permanente, the 1-year cardiovascular hospitalization, mortality, and cardiovascular mortality has been improved from 1998 to 2008 but remained high at 29.6\%(Virani et 
al., 2020), although, current diagnosis and treatment strategies are still ineffective in many patients, and drug treatment is associated with many complications and adverse reactions. Therefore, it is necessary to improve the current symptomatic treatment methods by innovating therapies to ideally target the specific pathological mechanism of HF. The exploration of the pathogenesis of HF and the research of HF therapeutic drugs are very dependent on basic and preclinical studies. In these studies, the research on the transformation process from the test bench to the clinical needs highly relevant experimental models to carry out accurate relationship research. In view of the complex causes of heart failure, current animal models used for HF research covers much of the models commonly used for CVDs research. Therefore, this paper firstly starts with a comprehensive overview of different models in various species currently used in HF research and discuss their general applicability. After that,we summarized the preclinical research review of approved drugs for HF, which would provide theoretical and practical guidance for researchers considering preclinical studies for the treatment of HF.

\section{Small animals and large animals, which is better for HF preclinical study?}

Prior to preclinical research implementation, the following two issues need to be settled: (1) primarily, what is the preferred species for mimicking the pathophysiology of cardiovascular conditions in human? And (2) secondly, which type of animal model is most suitable for HF research.

To address the first question, it would be appropriate in the first place to access the physiological and cardiovascular parameters across species. As is well known, each species develops its cardiovascular system at varying angles of orientation during evolution. Animal physiological parameters (Table 1 ), such as body temperature and heart rate, have been known to be essential parameters for species survival. Some of the parameters, including blood pressure and body temperature, are relatively constant among different species (Table 1 ). Whereas other parameters, like heart rate and respiratory rate, are in general inversely proportional to the animal size. For instance, mice body size is smaller and exhibits a higher heart rate than pigs (Table 1), one of the reasons can be attributed to the shorter duration of diastole in mice. Mice need to match the shorter time constant of the diastolic pressure decay, which can guarantee them adequate coronary perfusion to maintain the balance between cardiac metabolism and heart rate (Westerhof \& Elzinga, 1993). Besides general physiological parameters, speciation also produce differences in cardiac function parameters among species (Table $\mathbf{1}$ ). Clinically, echocardiography is the first-line technique for diagnostic evaluation and prognostic stratification of patients with heart failure. The left ventricular ejection fraction (LVEF) derived from echocardiography is usually used to quantify cardiac dysfunction,with EF value [?] $50 \%$ accept as normal. This diagnostic criterion has been extended to animal models of HF research. Most of the stimulus for heart failure, such as ischemia reperfusion, aortic stenosis, chemical agents, etc., could induce phenotype of heart failure with reduced ejection fraction (HFrEF) (Table 2 ). Besides this, Other echocardiographic parameters are also primary criteria for recognizing specific cardiovascular subtype of animal model or conditions amenable to specific treatment (Table 1 ). Take Dahl salt-sensitive rat model (described in detail below) as an example, fed them with high salt diet at different weeks of age may produce very different clinical phenotypes of systolic versus diastolic failure (Doi et al., 2000), which can be identified by echocardiographic parameters of each model, including fractional shortening (FS) and peak positive value of the first derivative of $\mathrm{LV}$ pressure $(+\mathrm{dP} / \mathrm{dtmax})$ (Table 1$)$.

Summing up the above arguments, when the pathological or pharmacological studies on HF are conducted with the rodents as the research object, due to the main species differences between rodents and human, the above mentioned physiological or cardiovascular parameters detected through the experimental model of this species may not resemble the HF phenotype observed in human. However, Small species is a more desired model in cardiovascular research due to the advantages it imparts with respect to experimental period and maintenance costs. Therefore, to avoid the huge cost associated with clinical failure, it is usually necessary to verify in an animal model (usually a large animal model) with less difference from human species after 
preclinical research of rodents, such as dogs, pigs and primates. In the state of consciousness, appropriate direct measurement of cardiovascular function can supplement early rodent research, and can be used as a better tool for translational research (Y.-T. Shen, Chen, Testani, Regan, \& Shannon, 2017). In addition, if conditions permit, although the use of non-human primates in medical research is generally very limited, accounting for only $<0.3 \%$ of the experimental animals used, the addition of non-human primate models to preclinical studies is also a necessary choice to avoid the risk of clinical failure. Non-human primates are considered to be important transformation models because they have unique advantages similar to humans in physiology, metabolism, biochemistry and heredity.

\section{Overview of the current animal models for heart failure}

The second challenge for HF preclinical research is the selection of the experimental model. Several previous and recent reviews provide a framework for the present discussion (Gomes, Falcao-Pires, Pires, Brás-Silva, \& Leite-Moreira, 2013; Houser et al., 2012; Patten \& Hall-Porter, 2009; Riehle \& Bauersachs, 2019; Y.-T. Shen et al., 2017; Silva \& Emter, 2020). Building on these works, we introduced current preclinical animal models according to the most common triggers for HF, including ischemia, hypertension, dilated cardiomyopathy and valve disease. Since the process of generating various animal models has been described in many previous studies, we refrain from a detailed description of each modeling method. Instead, we emphasize the pathology features of HF that can be presented by the model and their application limitations (Figure 1, Table 2 ). Additionally, we summarized significant changes of hemodynamics and echocardiography derived parameters in each animal model (Table 2 ), which would provide practical guidance for researchers who considering preclinical studies for the treatment of HF.

\subsection{HF induced by myocardial ischemia}

Myocardial ischemia is one of the most common causes of HF, the imbalance between myocardial blood supply and demand can be spontaneous or precipitated by coronary artery disease (e.g., atherosclerosis or thrombosis) or can occur during periprocedural revascularization surgery performed to restore spontaneous ischemia (e.g., percutaneous coronary intervention or coronary artery bypass grafting) (Thygesen, Alpert, White, \& Infarction, 2007). There are three main techniques in the model of HF induced by myocardial ischemia/infarction: permanent (irreversible) coronary occlusion, ischemia/reperfusion and coronary microembolization. Consistent with the progress of clinical patients, these three techniques combine the characteristics of $\mathrm{HF}$ induced by myocardial ischemia, including the initial ischemic event, followed by decreased cardiac output and ejection fraction, eccentric hypertrophy, focal fibrosis in the ischemic area, activation of neurohormone system and decrease of cardiac reserve (Houser et al., 2012). Correctly identifying the response of different types of myocardial infarction to ischemia is not only paramount for optimizing the management of patients, but also an important feature to simulate the transformation study of acute myocardial infarction induced HF.

\subsubsection{Permanent coronary artery occlusion}

Coronary artery ligation that simulates myocardial infarction (MI) is the most commonly used model of HF in small animals, which was first described in mice by Zolotareva et al (Zolotareva \& Kogan, 1978). After that, the pioneering study in rats by Pfeffer et al.(J. M. Pfeffer, Pfeffer, \& Braunwald, 1985) proved that infarct size, post-MI LV chamber dilatation and LV function are correlated. Their subsequent findings regarding the improvement of Captopril (an ACE inhibitor) on the contractile function and survival rate of rats (M. Pfeffer, Pfeffer, Steinberg, \& Finn, 1985) and patients (M. A. Pfeffer et al., 1992) after myocardial infarction, contribute to the establishment of the pharmacological ACE inhibitor treatment strategy, which has become a standard first-line treatment for HF.

As is well known, the infarct size is closely related to the duration of coronary artery occlusion. In most 
species, the shortest time required for coronary artery occlusion to induce MI should not be less than 20-30 minutes, which provides a definite and smallest size of MI. In the study of coronary artery ligation in small animals, the surviving mice gradually developed into HF during the 2.5 - 9 week period post-surgery (Gao, Dart, Dewar, Jennings, \& Du, 2000). The infarct size varies significantly from $15.2 \%$ to $55.2 \%$ of the left ventricle mass, which is directly related to the degree of left ventricular dysfunction and affects the time course of HF development (Gao et al., 2000; M. A. Pfeffer et al., 1979). Rats with infarctions greater than $46 \%$ had congestive heart failure, with elevated filling pressures, reduced cardiac output, and a minimal capacity to respond to pre- and after load stresses. In addition, other factors, including age (Gould et al., 2002), sex (Wu, Nasseri, Bloch, Picard, \& Scherrer-Crosbie, 2003) and genetic background (van den Borne et al., 2009) of animals also exert complex integrated effects on the time course of HF development induced by this model.

In large animals, such as pigs and sheep, irreversible coronary occlusion can be performed in the left anterior descending coronary artery (LAD) or left circumflex coronary artery (LCx) by acute ligation(Van der Velden et al., 2004), or thrombogenic coil (CHARLES, ELLIOTT, NICHOLLS, RADEMAKER, \& RICHARDS, 2000), hydraulic occlude (Y. T. Shen \& Vatner, 1996) and ameroid constrictor (Chekanov et al., 2003; O'konski, White, Longhurst, Roth, \& Bloor, 1987) placement. The former is an immediate approach to develop acute MI, whereas hydraulic occlude, thrombogenic coil or ameroid constrictors placement can mimic MI resulting from coronary stenosis due to progressive atherosclerotic plaque formation. These methods can produce phenotypes similar to those of small animals, including the initial observation of MI and the subsequent induction of a significant decrease of ejection fraction by $25 \%$ to $35 \%$ (J. Zhang et al., 1996). Besides, this model can also increase LV weight and LV end-diastolic area. It is worth noting that the location of coronary artery occlusion or ligation is related to the infarct size. In pigs or dogs, compared with LCx ligation, LAD occlusion leads to a relatively larger infarct size(Becker, Schuster, Jugdutt, Hutchins, \& Bulkley, 1983). Additionally, infarct size differs among species and among lines of the same species in this model. For instance, beagle dogs have a larger infarct size than mongrel dogs(Uemura et al., 1989). Other studies that examined obese Ossabaw swine by LCx ameroid constrictor placement resulted in a model of chronic ischemia as opposed to MI-induced HF because no or minimal subendocardial signs of infarction were observed (Elmadhun, Lassaletta, Chu, \& Sellke, 2013).

One potential limitation of the irreversible coronary occlusion animal model is permanent occlusion of myocardial vascular flow, which is contrary to the clinical features of patients with progressive non-occlusive coronary artery occlusion. Patients have infarct-related arteries due to spontaneous thrombolysis or reperfusion by fibrinolytic enzyme or balloon angioplasty, which cannot be reproduced in this model. In addition, this model has a high mortality rate due to acute heart failure or LV rupture within the first week post-MI (Gao et al., 2000).

\subsubsection{Ischemia-reperfusion model}

To overcome the limitations of irreversible coronary artery occlusion in animal model, ischemia/reperfusion (I/R) models have been established in different species. Ischemia/reperfusion will block the coronary blood flow to the myocardium and then reintroduce the blood flow into the ischemic area. This is helpful to study the molecular mechanisms and tissue damage after temporary occlusion of LAD. Compared with permanent left anterior descending branch occlusion, ischemia/reperfusion model shows less tissue damage compared to permanent LAD occlusion. Advantages of this model include a high survival rate, adjustable MI size according to coronary artery occlusion site, reproducible cardiac dysfunction and relatively low invasive methods (Bikou, Watanabe, Hajjar, \& Ishikawa, 2018).

Lots of works has been carried out on I/R model in small animals (Michael et al., 1995; Podesser et al., 2002; Reitz et al., 2019; Shimizu et al., 2018), from which left coronary artery occlusion for 45-60 minutes followed by reperfusion usually leads to HF 4 weeks post-surgery in mice (Reitz et al., 2019; Shimizu et al., 2018), with signs of HF including increased left ventricular (LV) internal diastolic (LVIDd) and systolic (LVIDs) dimensions, along with decreased ejection fraction (\% EF) and fractional shortening (\% FS) (Reitz et al., 
2019). In large animals, I/R is commonly used in left anterior LAD or LCx, which is produced by reversible ligation or inflation of an intracoronary angioplasty balloon (Bikou et al., 2018). Although dogs have been used for I/R research in history, the extensive coronary collateral circulation in canine hearts limits the use of this model. As pigs and sheep share the similar coronary arteries as humans (including gross anatomical structure and absence of existing collateral vessels), the I/R approach can be used to induce infarcts of predictable size and location in these species (Y.-T. Shen et al., 2017). Moreover, the infarct size produced by I/R may vary with different surgical sites, in general, using the I/R protocol of proximal occlusion of LAD would lead to more serious diseases, which indicates that it may be a better preclinical model (Ishikawa et al., 2014). The pathological features of HF induced by $\mathrm{I} / \mathrm{R}$ include the acute increase of natriuretic peptide level and cardiac troponin T, the progressively increased LV volume and the decreased EF (CHARLES et al., 2000). Limitations of pig and sheep I/R models include severe acute susceptibility to arrhythmia, and difficulty in imaging the heart with ultrasound techniques due to differences in ruminant dependence in gastrointestinal anatomy.

\subsubsection{Coronary microembolization}

Repeated coronary microembolization not only avoids the risk of severe acute myocardial infarction, but also mimics the chronic ischemic process caused by repeated ischemic injury. Contrary to coronary artery ligation or ameroid constrictor placement, HF with different degrees of left ventricular dysfunction can be produced in closed chest model by repeated coronary microembolization. This protocol has been investigated in very distinct species, but predominantly apply to the practices of translational study in large animals, by injecting glass (Franciosa, Heckel, Limas, \& Cohn, 1980) or polystyrene microspheres(Sabbah et al., 1991) (with various diameters depend on materials) into the LAD or LCx coronary artery. The regional contractile dysfunction induced by microspheres is proportionate to the number of injected particles (Erbel \& Heusch, 2000). In a study on canine model three months post-surgery (Sabbah et al., 1991), reductions in cardiac output and function were observed and were associated with a transmural MI distributed throughout the LV, septum, and right ventricle. Signs of HF include decreased EF, LV dilatation (increased end diastolic volume), increased pulmonary artery wedge pressure, systemic vascular resistance and plasma atrial natriuretic peptide and/or norepinephrine. This model has been successfully used in many pharmacological studies aimed at preventing the remodeling process of LV failure. In a separate study, Sabbah et al. showed dopamine $\beta$ -hydroxylase treatment can reduce the continuous increase of end diastolic and end systolic volumes, thus preventing progressive LV dysfunction and remodeling (Sabbah et al., 2000). In another similar study, longterm treatment with bosentan (a mixed endothelin-1 receptor antagonist A and B) can prevent the progress of LV dysfunction and weaken LV chamber remodeling in dogs with moderate HF induced by multiple consecutive intracoronary embolization (Mishima et al., 2000).

Repeated coronary microembolization can mimic the chronic effect of myocardial ischemia increasing with time. However, this process requires an intracoronary injection technique, which is usually performed under the anesthesia of a special catheter inserted into a specific area or implanted into a coronary artery for a long time. In addition, it is difficult to find a consistent protocol for the number of injections and the amount of microembolization (Y.-T. Shen et al., 2017). Therefore, this model is not easy to be repeated by most laboratories.

\subsection{HF induced by systemic hypertension}

In the United States, $46 \%$ of adults suffer from hypertension, which is the main risk factor for brain, heart and kidney events (Virani et al., 2020). Moreover, $17 \%$ of patients with HF were induced by hypertension (Virani et al., 2020). In understanding that hypertension pathophysiology is complex and not definitive, it is difficult to establish an animal model simulating clinical hypertension. 


\subsubsection{Transgenic animal models}

The most widely used model of HF induced by hypertension is transgenic animal models, including spontaneously hypertensive rat (SHR), spontaneously hypertensive HF (SHHF) rat and DS rat, etc.

As early as 1960s, Okamoto et al. (Okamoto \& Aoki, 1963) have produced spontaneously hypertensive rat (SHR), which is a natural model of pressure overload. Systemic hypertension in SHR mice gradually attacks with age and leads to obvious CHF at the age of 18-24 months, which is characterized by increased end-diastolic and end-systolic volumes and depressed EF in LV (Bing et al., 1995). With these features, this model is suitable for studying the transition from hypertrophy to CHF and replicating CHF induced by hypertension in human. On the basis of SHR mice, a further developed subspecies, SHR stroke prone (SHRSP), was developed, which would quickly develop severe hypertension with salt diet and has a strong tendency to die of stroke within a few weeks (Yamori, 1991). Another commonly used Transgenic lines for HF study is Spotaneously Hypertensive HF (SHHF) rat, which carry the facpobesity gene that encodes a defective leptin gene, to enable them develop noninsulin-dependent diabetes mellitus, obesity, hypertension and CHF (McCune, Baker, \& Stills Jr, 1990; McCune, Park, Radin, \& Jurin, 1995). Of notice, the time course for the development of HF depends on the dosage of facp gene (McCune et al., 1995). Besides, hypertension, plasma renin activity and male gender are independent factors contributing to cardiac hypertrophy and HF in this rat model (Holycross, Summers, Dunn, \& McCune, 1997). When compared to SHR rats, SHHF rats would have suffer from HF earlier with loss of cardiac function begins at age of 15 months (Heyen et al., 2002). And similar to SHRs, male animals are more likely to suffer from HF than female animals (Park, Liu-Stratton, Medeiros, Mccune, \& Radin, 2004). During the same period SHR rat emerged, a model of salt sensitivity, namely the Dahl-salt-sensitive (DS) rat was also developed, characterized by susceptibility to develop different degrees of hypertension depending on the variations in sodium intake (Dahl, Heine, \& Tassinari, 1962). DS rats fed with high diet at age of 7 or 8 week would develop different phenotypes of hypertensive heart failure (Doi et al., 2000), which is suitable for studying the transition from compensatory hypertrophy to failure. Generally speaking, the main advantage of these models is that they avoid the complications related to surgery or drug intervention, and can imitates the clinicopathologic features of $\mathrm{HF}$ induced by human essential hypertension.

\subsubsection{Renal artery stenosis}

In addition to genetic animal models, the most direct way to mimic the pathological changes of patients with hypertension is to perform surgery through kidney clipping or wrapping. As early as 1934, since Goldblatt et al. introduced an elevation of blood pressure by constriction of both main renal arteries of dog (Goldblatt, Lynch, Hanzal, \& Summerville, 1934), the Goldblatt Hypertension method (including Two-kidney, one clip [2K1C] and one-kidney, one clip [1K1C] hypertension) has been extensively studied and was successfully applied to the renal induced models of hypertension in rats (Junhong et al., 2008), rabbits (Kumagai, Suzuki, Ryuzaki, Matsukawa, \& Saruta, 1990) and sheep(Lau et al., 2010). Animal undergo 2K1C or 1K1C surgery would induce clinical signs of HF. In a rat model study, $2 \mathrm{~K} 1 \mathrm{C}$ can induce systemic hypertension and LV concentric remodeling within 8 weeks (Junhong et al., 2008). In another, 1K1C on sheep for 3-11 weeks showed elevated blood pressure, enlarged LA and reduced LAEF (Lau et al., 2010). Another model named "Page model", which can be produced by wrapping one or both kidneys in cellophane, has been historically used for dogs to develop systemic hypertension (Page, 1939). Systemic hypertension induced by bilateral renal wrapping on aged dogs can model several aspects of structural and functional characteristics described in the limited studies of human diastolic HF, including LV hypertrophy, myocardial fibrosis, and isolated diastolic dysfunction, which provides insight into the pathogenesis of diastolic HF (Munagala, Hart, Burnett Jr, Meyer, \& Redfield, 2005).

\subsection{HF failure induced by dilated cardiomyopathy}

The phenotype of Dilated cardiomyopathy (DCM) is induced by many primary and secondary causes(Houser et al., 2012). Primary diseases only affect myocardium (idiopathic DCM), whereas secondary causes are ex- 
tensive, with most commonly clinical signs being coronary artery disease, myocardial infarction (ischemic cardiomyopathy) and long-term hypertension. Other causes include myocarditis (especially viral), chemotherapy drugs (such as anthracyclines), persistent and inappropriate tachycardia, etc. Consistent with these clinical incentives, DCM can be induced by the above-mentioned ischemic injury/myocardial infarction and systemic hypertension, as well as toxic injury, rapid ventricular pacing, pressure overload and volume overload described below. These models can be used to define hemodynamic, mechanical, neurohormonal, cellular and molecular changes during HF, and to evaluate the potential efficacy of new therapies.

\subsubsection{Chemical induced model}

Both small animals (e.g. mice and rats), or large animals (e.g. dogs, sheep and pig) can be used to as toxic DCM model induced by intracoronary adriamycin or isoprenaline. These chemical agents can produce dose-dependent dilated phenotype associated with arrhythmias, myocyte loss, and fibrosis, with progression to heart failure. Sheep undergo sequential intracoronary injections of adriamycin causing a dilated phenotype with dramatically reduced EF and increased LV volumes, resulting in decrease of LV wall thickness and eventually in HF (Borenstein et al., 2006). These models are particularly attractive as it easy to perform in common laboratories without the need of surgical procedures. However, the disadvantages of these methods are also obvious, including the variability of response to doxorubicin, the degree of LV dysfunction, animal mortality caused by arrhythmia, and engenders several systemic side effects, such as bone marrow suppression, gastrointestinal discomfort.

\subsubsection{Rapid ventricular pacing model}

DCM induced by persistent and inappropriate tachycardia can be simulated by rapid ventricular pacing model, which is commonly applied to large animal studies, mostly in the canine model (Byrne et al., 2002; Shannon, Komamura, Shen, Bishop, \& Vatner, 1993; Spinale et al., 1997; Takagaki et al., 2002). Rapid pacing can be performed by pacing leads implanted in the atrium, right atrium or left atrium, to lead to a rapid and significant decline in cardiac function, thus meeting the hemodynamic conditions of HF. The severity of cardiac dysfunction depends on the two factors: pacing rate and duration, of which the pacing rate is controlled by programmable internal or external pacemakers in the range of 200-300 bpm according to specific conditions, while the duration of pacing varies from a few days to several weeks (Y.-T. Shen et al., 2017). This model can cause high output HF, accompanied by biventricular dilatation, a deterioration of systolic and diastolic function and activation of neurohormone axis. Along with progressive HF, plasma catecholamine levels increase. At more advanced stages, the levels of endothelin and renin increased and the density of $\beta$ receptor decreased, all of which closely resembling the phenotype of CHF in human. However, a major drawback of rapid ventricular pacing model is that the cardiovascular hemodynamics and biochemical alterations would progressively revert to near baseline levels after pacing stopped (Byrne et al., 2002).

\subsubsection{Transgenic animal models}

In small animals, two mouse strains were established in rodents to simulate the development, progression and regression of human DCM. A muscle LIM protein (MLP)-/-mouse developed by the deletion of actin-related cytoskeleton protein (Arber et al., 1997), which gradually decreases heart function from 4 to 6 months after birth and continues to develop into dilated cardiomyopathy with hypertrophy and HF. The other is calcium binding protein calsequestring (CSQ) mice produced by cardiac-restricted overexpression of the CQS in the (Sato et al., 1998) heart. By echocardiography, CSQ mice showed mild LV enlargement at 7 weeks, and mild decreased fractional shortening with increased wall thickness. At age of 14 weeks, the phenotype developed into obvious LV enlargement and severe systolic function decline (Cho et al., 1999). In addition, these two mouse strains replicate other aspects of human dilated cardiomyopathy, including abnormal $\beta$-adrenergic receptor $(\beta-A R)$ signal transduction. 


\subsection{HF induced by dilated cardiomyopathy}

Typical symptoms of HF, including shortness of breath, peripheral and pulmonary edema, and low exercise tolerance, can be caused by two types of valve lesions: aortic stenosis (AS) (abnormally high ejection resistance prevents the valve from fully opening) or mitral regurgitation (MR) (a failure of complete coaptation of the leaflets and adequate closure) (Houser et al., 2012). Although these two types of valve disease will eventually lead to HF events such as LV diastolic/atrial pressure, fluid retention and fatigue, they have different underlying pathophysiological characteristics. The former can lead to significant LV pressure overload, whereas the latter causes a significant LV volume overload.

\subsubsection{Transverse aortic constriction}

In small animals, the most widely used model of aortic stenosis is the Transverse aortic constriction (TAC), which is characterized by an initial compensatory phase with concentric LV hypertrophy, followed by enlargement of the cardiac chamber with further deterioration of LV function, and eventually leading to HF. These characteristics are similar to the progression of human HF, particularly in patients with aortic stenosis. Therefore, TAC is often used to induce chronic LV pressure overload and hypertrophy in rodents (Boluyt et al., 2005; Li et al., 2012; Litwin et al., 1995). Several TAC surgical techniques have been developed, including a minimally invasive approach by making a small incision in the proximal sternum, and placement of surgical clips, sutures, or O-rings to prevent blood flow through the aortic arch (Riehle \& Bauersachs, 2019). Besides constriction at TAC, the surgical constriction can also be performed at other locations, including ascending aortic constriction (AAC), or abdominal aorta. These models result in varied effects depending on the anatomic location of the constriction, in general, constriction at AAC is used to study the effects of early injury due to pressure overload, while TAC and suprarenal aortic coarctation appear as more gradual increases in pressure leading to hypertrophy and HF (Gomes et al., 2013). Moreover, factors that affect the hypertrophy response and progression in HF include sex, body weight, age, and genetic background of the species used (Barrick, Rojas, Schoonhoven, Smyth, \& Threadgill, 2007). Several studies have also described in large animal models with progressive aortic contraction on supravalvular position (Moorjani et al., 2006; Tagawa et al., 1998; Ye, Gong, Ochiai, Liu, \& Zhang, 2001). These animal models replicate many key characteristics of human aortic stenosis, including the gradual increase of LV aortic pressure gradient and compensatory LV remodeling reaction, accompanied by myocardial hypertrophy, cellular hypertrophy with evidence of diastolic HF and abnormal myocardial matrix. The shortcomings of TAC model are that they do not possess some of the key features of human disease, including the inability to easily induce slowly progressive stress overload, and other limitations include the long duration of the experimental protocol, variability in the individual response to stress overload, and a reduction in the high proportion of constriction due to internalization of the contractile knot.

\subsubsection{Chordae tendineae cutting}

Mitral valve insufficiency leads to chronic volume overload, resulting in compensatory LV hypertrophy, followed by dilatation with pulmonary edema. In large animals (most commonly the dog or sheep), significant clinical phenotype of chronic mitral regurgitation can be induced by cutting chordae tendineae (Leroux, Moonen, Pierard, Kolh, \& Amory, 2012; Nielsen et al., 2003). MR occurs in canine model leads to LV dilatation and eccentric LVH pattern, which is accompanied by the increase of muscle cell length, the change of myofilament structure and the decrease of myofibril content. Different from LVH in large AS animal model, chronic MR in dogs can lead to severe LV contractile dysfunction at both levels of chamber and myocyte (Spinale et al., 1993). This chronic MR model has been successfully used to test the role of angiotensin II receptor pathways in the progression of HF (Perry et al., 2002). Although the use of angiotensin II type-1 (AT1) receptor blocker $\left(\mathrm{AT}_{1} \mathrm{RB}\right)$ in this study reduced systemic vascular resistance and local expression of the renin-angiotensin system in the MR dog model, it did not prevent adverse left ventricular and myocardial cell remodeling in the early myocardial adaptive phase of MR.

To date, there is no universally accepted model for MR in small animals. Some such attempts have been 
made by Min et al. (Kim et al., 2012), who develop a rat MR model by inserted a fine needle (0.36 $\mathrm{mm}$ in diameter) into LV through the apex of LV, followed by pushing a needle into the mitral valve to puncture and/or tear the mitral leaflets to form MR. In this model, the time course of LV remodeling and functional change is similar to that of human. Since this MR model was created by perforating the mitral leaflet, it does not represent MR in human, particularly ischemic MR, which is an inherent limitation of animal models of valvular disease. However, it can still be used as an inexpensive model for evaluating the effects of drug therapy on MR-induced LV remodeling, which is important for clinical translational research.

\section{What implications do the present findings have for preclinical practice in HF?}

In the past three decades, there have been few areas of medicine where significant progress has been made in the treatment of HF. However, progress was consistent only in chronic HF with reduced ejection fraction. In acute decompensated $\mathrm{HF}$ and $\mathrm{HF}$ with preserved ejection fraction, no treatment has been proven to improve survival. At present, several kinds of drugs on the market, such as ACE inhibitors, angiotensin II receptor blockers type I (ARB), beta blockers (BBS), aldosterone receptor blockers (ALRB), statins, as well as anticoagulant and anticoagulant therapy, have proved to be effective in achieving hard targets; however, the mortality reduction of most drugs is less than $30 \%$ and the residual cardiovascular risk is still high. Therefore, efforts to find new methods in the field of HF treatment have not stopped, and HF treatment drugs based on new mechanisms are constantly being discovered (Table 3 ). One of the most remarkable is the unexpected harvest of SGLT2 inhibitors in the treatment of HF. In May 2020, farxiga (empagliflozin) successfully passed the fast track qualification (FTD) and became the first SGLT2 inhibitor approved for the treatment of HF. In preclinical studies, the rate of cardiac remodeling in the non-diabetic pig model group with left anterior artery ischemia treated by empagliflozin decreased (Santos-Gallego et al., 2019). Although the precise mechanism of SGLT2 in treating HF is not clear, it put forward new demands for cardiovascular disease research, that is, to study on more complex disease models.

\subsection{Study on animal model of HF induced by multiple stimulus}

In view of the outstanding contribution of SGLT2 inhibitors in the treatment of heart failure, it suggests that these diseases have a common pathogenesis, However, many pharmaceutical companies and scientists currently focus on developing a single "mechanism" therapy. As outlined in the previous section, in the past century, many research institutions and investigators worldwide have developed a large number of animal models and assessment methods, which cover different aspect that could resemble clinical characteristics HF in human. Therefore, the key to successful preclinical development in the future lies not in developing more HF models, but in modifying existing animal models to better imitate complex clinical situations. As initiating triggers for $\mathrm{HF}$ pathologies are highly diverse and the disease processes typically complex, each animal model of HF produced by single stimulus has obvious defects, so the combination strategy produced by multiple stimuli may be a better model to mimic disease conditions in human. There are already many ongoing efforts in this regard. Given the limitation of the reversible nature of rapid pacing model alone, Shen et al. combined rapid ventricular pacing with sequential coronary artery occlusion and banding aorta respectively, developed two multi-stimulus induced animal models (Y.-T. Shen et al., 2017). From which it was observed that banding aorta alone (which would cause left ventricular hypertrophy) did not reduce baseline cardiac function. But when myocardial ischemia or left ventricular hypertrophy is combined with pacing, decreased left ventricular $\mathrm{dP} / \mathrm{dt}$ and increased left ventricular end diastolic pressure was observed. The combination of two different methods provides a better model to mimic the clinical phenotype of human heart failure, which would provide a unique opportunity for elucidation of cardiovascular disease mechanisms and also the evaluation of novel interventions. In some other studies, stimulus combined with transgenic animal models has become a common strategy for studying pathology and pharmacology of HF. 


\subsection{Highlighting the application of biomarker detection in animal model study}

The frequency of positive Phase III clinical trials with investigational HF drugs has decreased over the past 20 years, while the rate of positive Phase II clinical trials with surrogate end points remains high. Although there are many compelling cases of biological plausibility, past experience strongly suggests that there is no reliable surrogate end point for the Phase III HF trial outcome (Greene et al., 2018). It has been found that the development of novel biomarkers may be more effective than the use of surrogate end points, and the evaluation of biomarkers is more repeatable and results more reliable in animal models than mimicking complex cardiovascular disease. Biomarkers can help detect the presence of heart failure, determine its severity, assess the risk of future events, and guide treatment, when in combination with clinical and physical assessments can provide greater diagnostic accuracy than physical assessments alone (Chow et al., 2017). Since the establishment of natriuretic peptide as a diagnostic criterion for heart failure in 2000, the evaluation of biomarkers has been included in a large number of preclinical studies (Januzzi \& Felker, 2013). However, defining a "rule-in" cutoffs for HF is complicated because multiple factors influence natriuretic peptide levels for heart failure is complex because of a variety of factors that affect natriuretic peptide levels. Thus, other potential strategy explored a multimarker approach for predicting new-onset HF. In the subset of patients with high baseline risk determined by clinical parameters, the best models for predicting new onset HF include N-terminal pro-B-type natriuretic peptide (NT-proBNP), troponin T (TnT), and urinary albumin excretion(Chow et al., 2017). Introducing these indicators of biomarkers into animal model research not only can be used to distinguish the subtypes of HF of animal models with different clinical features, but also can help evaluate the pharmacological efficacy studies of drugs by combining the results from physiological and echocardiography parameters. Indeed, biomarkers have been used in association with many preclinical studies that have been completed or are ongoing (Table 2 ). Recently, a novel study demonstrated an increase in NT-proBNP levels in the dog I/R model, in contrast, LV mechanical unloading by the total support of transvascular LV assist device Impella could reduce LV end-diastolic pressure, increase LV end-systolic elastance and decrease NT-proBNP level, thereby preventing subsequent HF (Saku et al., 2018).

\section{Summary and conclusion}

In the process of preclinical drug discovery, due to the complex nature of the dynamic heart, which is not only affected by the proteins and processes in the heart, but also affected by the dynamic changes and interaction of biophysical mechanical forces and currents in the process of beating heart, no animal model is perfect for interpreting every aspect of cardiovascular pathology at one time, thus many of the complex properties thus cannot be captured by a vitro cell model or an in vivo animal alone. Instead, the preclinical pharmacological evaluation of HF often involves in preliminary studies conducted in vitro (including cells and isolated tissues) to identify potential drug targets, new signaling pathways, and regulatory mechanisms, then moving to comprehensive characterization in rodents and large animals (Table 3 ). We summarized the main strengths and weaknesses of these approaches and their applicability to preclinical process in HF research (Figure 2 ). Based on this, we strongly recommend that careful consideration be given to the potential impact of species selection on experimental data during drug research, as well as the physiological conditions for data collection. It is not only limited to small rodent studies, but also should be evaluated by multiple model methods, especially involving the verification of cardiac characteristics in large mammals or humans, so as to promote drug discovery of HF. In addition, we should consider the factors such as complications and side effects while meeting the established research objectives. The therapeutic effect of preclinical HF candidate drugs needs to be supported in a variety of different experimental models. As called for in the scientific statement written by Houser et al., (Houser et al., 2012) a "one size fits all" approach is not suitable for the selection of experimental models for the study of HF. Instead, animal models should be selected based on the characteristics present in the particular clinical form of $\mathrm{HF}$ of interest. 


\section{CONFLICT OF INTEREST}

The authors declare that they have no conflict of interest.

\section{ACKNOWLEDGEMENTS}

XW was supported by the British Heart Foundation (PG/17/31/32988, PG/19/53/34499, PG/19/66/34600 and FS/19/39/34447). ZW, LC, ZC, TW, ZW, and WX were supported by the Jiangsu 2020 Special Project for Transformation and Upgrading of Industry and Information Industry.

\section{REFERENCES}

Alhumaidha, K. A., Saleh, D. O., Abd El Fattah, M. A., El-Eraky, W. I., \& Moawad, H. (2016). Cardiorenal protective effect of taurine against cyclophosphamide-induced toxicity in albino rats. Canadian journal of physiology and pharmacology, 94 (2), 131-139.

Arber, S., Hunter, J. J., Ross Jr, J., Hongo, M., Sansig, G., Borg, J., . . Caroni, P. (1997). MLP-deficient mice exhibit a disruption of cardiac cytoarchitectural organization, dilated cardiomyopathy, and heart failure. Cell, 88 (3), 393-403.

Barrick, C. J., Rojas, M., Schoonhoven, R., Smyth, S. S., \& Threadgill, D. W. (2007). Cardiac response to pressure overload in 129S1/SvImJ and C57BL/6J mice: temporal-and background-dependent development of concentric left ventricular hypertrophy. American Journal of Physiology-Heart and Circulatory Physiology, 292 (5), H2119-H2130.

Becker, L., Schuster, E., Jugdutt, B., Hutchins, G., \& Bulkley, B. (1983). Relationship between myocardial infarct size and occluded bed size in the dog: difference between left anterior descending and circumflex coronary artery occlusions. Circulation, 67 (3), 549-557.

Bikou, O., Watanabe, S., Hajjar, R. J., \& Ishikawa, K. (2018). A pig model of myocardial infarction: catheter-based approaches. InExperimental Models of Cardiovascular Diseases, (pp. 281-294): Springer.

Bing, O. H., Brooks, W. W., Robinson, K. G., Slawsky, M. T., Hayes, J. A., Litwin, S. E., .. Conrad, C. H. (1995). The spontaneously hypertensive rat as a model of the transition from compensated left ventricular hypertrophy to failure. Journal of molecular and cellular cardiology, 27 (1), 383-396.

Boluyt, M. O., Robinson, K. G., Meredith, A. L., Sen, S., Lakatta, E. G., Crow, M. T., ... Bing, O. H. (2005). Heart failure after long-term supravalvular aortic constriction in rats. American journal of hypertension, 18 (2), 202-212.

Borenstein, N., Bruneval, P., Behr, L., Laborde, F., Montarras, D., Daurès, J. P., .. Chetboul, V. (2006). An ovine model of chronic heart failure: echocardiographic and tissue Doppler imaging characterization. Journal of Cardiac Surgery, 21 (1), 50-56.

Byrne, M. J., Raman, J. S., Alferness, C. A., Esler, M. D., Kaye, D. M., \& Power, J. M. (2002). An ovine model of tachycardia-induced degenerative dilated cardiomyopathy and heart failure with prolonged onset. Journal of cardiac failure, 8 (2), 108-115.

Carlsson, M., Wilson, M., Martin, A. J., \& Saeed, M. (2009). Myocardial microinfarction after coronary microembolization in swine: MR imaging characterization. Radiology, 250 (3), 703-713.

Charles, C. J., Elliott, J. M., Nicholls, M. G., Rademaker, M. T., \& Richards, A. M. (2003). Natriuretic peptides maintain sodium homoeostasis during chronic volume loading post-myocardial infarction in sheep. Clinical Science, 104 (4), 429-436. 
CHARLES, C. J., ELliOTT, J. M., NICHOLlS, M. G., RADEMAKER, M. T., \& RICHARDS, M. (2000). Myocardial infarction with and without reperfusion in sheep: early cardiac and neurohumoral changes. Clinical Science, 98 (6), 703-711.

Chekanov, V., Akhtar, M., Tchekanov, G., Dangas, G., Shehzad, M. Z., Tio, F., ... Leon, M. B. (2003). Transplantation of autologous endothelial cells induces angiogenesis. Pacing and clinical electrophysiology, 26 (1p2), 496-499.

Cho, M.-C., Rapacciuolo, A., Koch, W. J., Kobayashi, Y., Jones, L. R., \& Rockman, H. A. (1999). Defective $\beta$-adrenergic receptor signaling precedes the development of dilated cardiomyopathy in transgenic mice with calsequestrin overexpression. Journal of Biological Chemistry, 274 (32), 22251-22256.

Chow, S. L., Maisel, A. S., Anand, I., Bozkurt, B., De Boer, R. A., Felker, G. M., .. Kiernan, M. S. (2017). Role of biomarkers for the prevention, assessment, and management of heart failure: a scientific statement from the American Heart Association.Circulation, 135 (22), e1054-e1091.

Clauss, S., Bleyer, C., Schuettler, D., Tomsits, P., Renner, S., Klymiuk, N., ... Kääb, S. (2019). Animal models of arrhythmia: classic electrophysiology to genetically modified large animals. Nature reviews Cardiology, 16 (8), 457-475.

Conrad, C. H., Brooks, W. W., Hayes, J. A., Sen, S., Robinson, K. G., \& Bing, O. H. (1995). Myocardial fibrosis and stiffness with hypertrophy and heart failure in the spontaneously hypertensive rat.Circulation, 91 (1), 161-170.

Cotton, J. M., Kearney, M. T., MacCarthy, P. A., Grocott-Mason, R. M., McClean, D. R., Heymes, C., ... Shah, A. M. (2001). Effects of nitric oxide synthase inhibition on basal function and the force-frequency relationship in the normal and failing human heart in vivo. Circulation, 104 (19), 2318-2323.

Dahl, L. K., Heine, M., \& Tassinari, L. (1962). Role of genetic factors in susceptibility to experimental hypertension due to chronic excess salt ingestion. Nature, 194 (4827), 480-482.

Doi, R., Masuyama, T., Yamamoto, K., Doi, Y., Mano, T., Sakata, Y., ... Koyama, T. (2000). Development of different phenotypes of hypertensive heart failure: systolic versus diastolic failure in Dahl salt-sensitive rats. Journal of hypertension, 18 (1), 111-120.

Dokainish, H., Teo, K., Zhu, J., Roy, A., AlHabib, K. F., ElSayed, A., .. Yusoff, K. (2017). Global mortality variations in patients with heart failure: results from the International Congestive Heart Failure (INTERCHF) prospective cohort study. The Lancet Global Health, 5 (7), e665-e672.

Elmadhun, N. Y., Lassaletta, A. D., Chu, L. M., \& Sellke, F. W. (2013). Metformin alters the insulin signaling pathway in ischemic cardiac tissue in a swine model of metabolic syndrome. The Journal of thoracic and cardiovascular surgery, 145 (1), 258-266.

Erbel, R., \& Heusch, G. (2000). Coronary microembolization. Journal of the American College of Cardiology, $36(1), 22-24$.

Ferrarini, M., Arsic, N., Recchia, F. A., Zentilin, L., Zacchigna, S., Xu, X., .. Hintze, T. H. (2006). Adenoassociated virus-mediated transduction of VEGF165 improves cardiac tissue viability and functional recovery after permanent coronary occlusion in conscious dogs. Circulation research, 98 (7), 954-961.

Franciosa, J. A., Heckel, R., Limas, C., \& Cohn, J. N. (1980). Progressive myocardial dysfunction associated with increased vascular resistance. American Journal of Physiology-Heart and Circulatory Physiology, 239 (4), H477-H477.

Francis, J., Weiss, R., Wei, S., Johnson, A., \& Felder, R. (2001). Progression of heart failure after myocardial infarction in the rat.American Journal of Physiology-Regulatory, Integrative and Comparative Physiology, 281 (5), R1734-R1745. 
Gao, X.-M., Dart, A. M., Dewar, E., Jennings, G., \& Du, X.-J. (2000). Serial echocardiographic assessment of left ventricular dimensions and function after myocardial infarction in mice. Cardiovascular research, 45 (2), 330-338.

Goetzenich, A., Hatam, N., Zernecke, A., Weber, C., Czarnotta, T., Autschbach, R., \& Christiansen, S. (2009). Alteration of matrix metalloproteinases in selective left ventricular adriamycin-induced cardiomyopathy in the pig. The Journal of heart and lung transplantation, 28 (10), 1087-1093.

Goldblatt, H., Lynch, J., Hanzal, R. F., \& Summerville, W. W. (1934). Studies on experimental hypertension: I. The production of persistent elevation of systolic blood pressure by means of renal ischemia. The Journal of experimental medicine, 59 (3), 347-379.

Gomes, A., Falcao-Pires, I., Pires, A., Brás-Silva, C., \& Leite-Moreira, A. (2013). Rodent models of heart failure: an updated review. Heart failure reviews, 18 (2), 219-249.

Gould, K. E., Taffet, G. E., Michael, L. H., Christie, R. M., Konkol, D. L., Pocius, J. S., ... Sandusky Jr, G. E. (2002). Heart failure and greater infarct expansion in middle-aged mice: a relevant model for postinfarction failure. American Journal of Physiology-Heart and Circulatory Physiology, 282 (2), H615-H621.

Greene, S. J., Mentz, R. J., Fiuzat, M., Butler, J., Solomon, S. D., Ambrosy, A. P., .. O'Connor, C. M. (2018). Reassessing the role of surrogate end points in drug development for heart failure.Circulation, 138 (10), 1039-1053.

Gross, D. (2009). Animal models in cardiovascular research : Springer Science \& Business Media.

Hau, J., \& Schapiro, S. J. (2002). Handbook of laboratory animal science: Essential Principles and Practices, Volume I : CRC press.

Heyen, J. R., Blasi, E. R., Nikula, K., Rocha, R., Daust, H. A., Frierdich, G., .. Rudolph, A. E. (2002). Structural, functional, and molecular characterization of the SHHF model of heart failure.American Journal of Physiology-Heart and Circulatory Physiology, 283 (5), H1775-H1784.

Holycross, B. J., Summers, B. M., Dunn, R., \& McCune, S. (1997). Plasma renin activity in heart failureprone SHHF/Mcc-facp rats. American Journal of Physiology-Heart and Circulatory Physiology, 273 (1), $\mathrm{H} 228-\mathrm{H} 233$.

Houser, S. R., Margulies, K. B., Murphy, A. M., Spinale, F. G., Francis, G. S., Prabhu, S. D., .. Sussman, M. A. (2012). Animal models of heart failure: a scientific statement from the American Heart Association. Circulation research, 111 (1), 131-150.

Huang, Y., Kawaguchi, O., Zeng, B., Carrington, R., Horam, C. J., Yuasa, T., ... Hunyor, S. N. (1997). A stable ovine congestive heart failure model. A suitable substrate for left ventricular assist device assessment. ASAIO Journal (American Society for Artificial Internal Organs: 1992), 43 (5), M408-413.

Ikeda, Y., Yutani, C., Huang, Y., Masuda, K., Yuasa, T., Kawaguchi, O., \& Hunyor, S. N. (2001). Histological remodeling in an ovine heart failure model resembles human ischemic cardiomyopathy.Cardiovascular Pathology, 10 (1), 19-27.

Ishikawa, K., Aguero, J., Tilemann, L., Ladage, D., Hammoudi, N., Kawase, Y., ... Hajjar, R. J. (2014). Characterizing preclinical models of ischemic heart failure: differences between LAD and LCx infarctions. American Journal of Physiology-Heart and Circulatory Physiology, 307 (10), H1478-H1486.

Januzzi, J. L., \& Felker, G. M. (2013). Surfing the biomarker tsunami at JACC: heart failure. In: American College of Cardiology Foundation Washington, DC.

Junhong, W., Jing, Y., Jizheng, M., Shushu, Z., Xiangjian, C., Hengfang, W., . . Jinan, Z. (2008). Proteomic analysis of left ventricular diastolic dysfunction hearts in renovascular hypertensive rats.International journal of cardiology, 127 (2), 198-207. 
KE, I. H., Brooks, R., \& Warbaase, J. (1974). The rate of change of left ventricular volume in man. I. Validation and peak systolic ejection rate in health and di. Circularion, 59 , 729-738.

Kim, K.-H., Kim, Y.-J., Ohn, J.-H., Yang, J., Lee, S.-E., Lee, S.-W., .. Sohn, D.-W. (2012). Long-term effects of sildenafil in a rat model of chronic mitral regurgitation: benefits of ventricular remodeling and exercise capacity. Circulation, 125 (11), 1390-1401.

Klotz, S., Hay, I., Zhang, G., Maurer, M., Wang, J., \& Burkhoff, D. (2006). Development of heart failure in chronic hypertensive Dahl rats: focus on heart failure with preserved ejection fraction. Hypertension, 47 (5), 901-911.

Kumagai, H., Suzuki, H., Ryuzaki, M., Matsukawa, S., \& Saruta, T. (1990). Baroreflex control of renal sympathetic nerve activity is potentiated at early phase of two-kidney, one-clip Goldblatt hypertension in conscious rabbits. Circulation research, 67 (6), 1309-1322.

Lau, D. H., Mackenzie, L., Kelly, D. J., Psaltis, P. J., Worthington, M., Rajendram, A., .. Kuklik, P. (2010). Short-term hypertension is associated with the development of atrial fibrillation substrate: a study in an ovine hypertensive model. Heart Rhythm, 7 (3), 396-404.

Leroux, A. A., Moonen, M. L., Pierard, L. A., Kolh, P., \& Amory, H. (2012). Animal models of mitral regurgitation induced by mitral valve chordae tendineae rupture. The Journal of heart valve disease, 21 (4), 416-423.

Li, J. M., Yao, Z. F., Zou, Y. Z., Ge, J. B., Guan, A. L., Wu, J., .. Ma, Z. (2012). The therapeutic potential of G-CSF in pressure overload induced ventricular reconstruction and heart failure in mice.Molecular biology reports, 39 (1), 5-12.

Litwin, S. E., Katz, S. E., Weinberg, E. O., Lorell, B. H., Aurigemma, G. P., \& Douglas, P. S. (1995). Serial echocardiographic-Doppler assessment of left ventricular geometry and function in rats with pressureoverload hypertrophy: chronic angiotensin-converting enzyme inhibition attenuates the transition to heart failure.Circulation, 91 (10), 2642-2654.

Matsuda, M., Sugishita, Y., Koseki, S., Ito, I., Akatsuka, T., \& Takamatsu, K. (1983). Effect of exercise on left ventricular diastolic filling in athletes and nonathletes. Journal of Applied Physiology, 55 (2), 323-328.

McCune, S. A., Baker, P. B., \& Stills Jr, H. F. (1990). SHHF/Mcc-cp rat: model of obesity, non-insulindependent diabetes, and congestive heart failure. ILAR Journal, 32 (3), 23-27.

McCune, S. A., Park, S., Radin, M. J., \& Jurin, R. R. (1995). SHHF/Mcc-/fa cp Rat Model: A Genetic Model of Congestive Heart Failure. In Mechanisms of heart failure, (pp. 91-106): Springer.

Michael, L. H., Entman, M. L., Hartley, C. J., Youker, K. A., Zhu, J., Hall, S. R., ... Ballantyne, C. M. (1995). Myocardial ischemia and reperfusion: a murine model. American Journal of Physiology-Heart and Circulatory Physiology, 269 (6), H2147-H2154.

Mishima, T., Tanimura, M., Suzuki, G., Todor, A., Sharov, V. G., Goldstein, S., \& Sabbah, H. N. (2000). Effects of long-term therapy with bosentan on the progression of left ventricular dysfunction and remodeling in dogs with heart failure. Journal of the American College of Cardiology, 35 (1), 222-229.

Monnet, E., \& Orton, E. C. (1999). A canine model of heart failure by intracoronary adriamycin injection: hemodynamic and energetic results. Journal of cardiac failure, 5 (3), 255-264.

Moorjani, N., Ahmad, M., Catarino, P., Brittin, R., Trabzuni, D., Al-Mohanna, F., ... Westaby, S. (2006). Activation of apoptotic caspase cascade during the transition to pressure overload-induced heart failure. Journal of the American College of Cardiology, 48 (7), 1451-1458.

Munagala, V. K., Hart, C. Y., Burnett Jr, J. C., Meyer, D. M., \& Redfield, M. M. (2005). Ventricular structure and function in aged dogs with renal hypertension: a model of experimental diastolic heart failure. Circulation, 111 (9), 1128-1135. 
Nielsen, S. L., Timek, T. A., Green, G. R., Dagum, P., Daughters, G. T., Hasenkam, J. M., ... Miller, D. C. (2003). Influence of anterior mitral leaflet second-order chordae tendineae on left ventricular systolic function. Circulation, 108 (4), 486-491.

O'konski, M., White, F., Longhurst, J., Roth, D., \& Bloor, C. (1987). Ameroid constriction of the proximal left circumflex coronary artery in swine. A model of limited coronary collateral circulation. The American journal of cardiovascular pathology, 1 (1), 69-77.

Okamoto, K., \& Aoki, K. (1963). Development of a strain of spontaneously hypertensive rats. Japanese circulation journal, 27 (3), 282-293.

Oudit, G. Y., Crackower, M. A., Eriksson, U., Sarao, R., Kozieradzki, I., Sasaki, T., .. Wada, T. (2003). Phosphoinositide 3-kinase $\gamma$-deficient mice are protected from isoproterenol-induced heart failure. Circulation, 108 (17), 2147-2152.

Page, I. H. (1939). A method for producing persistent hypertension by cellophane. Science, 89 (2308), 273-274.

Park, S. C., Liu-Stratton, Y., Medeiros, L. C., Mccune, S. A., \& Radin, M. J. (2004). Effect of male sex and obesity on platelet arachidonic acid in spontaneous hypertensive heart failure rats. Experimental Biology and Medicine, 229 (7), 657-664.

Patten, R. D., \& Hall-Porter, M. R. (2009). Small animal models of heart failure: development of novel therapies, past and present.Circulation: Heart Failure, 2 (2), 138-144.

Perry, G. J., Wei, C.-C., Hankes, G. H., Dillon, S. R., Rynders, P., Mukherjee, R., .. Dell'Italia, L. J. (2002). Angiotensin II receptor blockade does not improve left ventricular function andremodeling in subacute mitral regurgitation in the dog. Journal of the American College of Cardiology, 39 (8), 1374-1379.

Pfeffer, J. M., Pfeffer, M. A., \& Braunwald, E. (1985). Influence of chronic captopril therapy on the infarcted left ventricle of the rat.Circulation research, 57 (1), 84-95.

Pfeffer, M., Pfeffer, J., Steinberg, C., \& Finn, P. (1985). Survival after an experimental myocardial infarction: beneficial effects of long-term therapy with captopril. Circulation, 72 (2), 406-412.

Pfeffer, M. A., Braunwald, E., Moyé, L. A., Basta, L., Brown Jr, E. J., Cuddy, T. E., .. Flaker, G. C. (1992). Effect of captopril on mortality and morbidity in patients with left ventricular dysfunction after myocardial infarction: results of the Survival and Ventricular Enlargement Trial. New England Journal of Medicine, 327 (10), 669-677.

Pfeffer, M. A., Pfeffer, J. M., Fishbein, M. C., Fletcher, P. J., Spadaro, J., Kloner, R. A., \& Braunwald, E. (1979). Myocardial infarct size and ventricular function in rats. Circulation research, 44 (4), 503-512.

Pilla, J. J., Blom, A. S., Brockman, D. J., Ferrari, V. A., Yuan, Q., \& Acker, M. A. (2003). Passive ventricular constraint to improve left ventricular function and mechanics in an ovine model of heart failure secondary to acute myocardial infarction. The Journal of thoracic and cardiovascular surgery, 126 (5), 1467-1475.

Pleger, S. T., Shan, C., Ksienzyk, J., Bekeredjian, R., Boekstegers, P., Hinkel, R., .. Qiu, G. (2011). Cardiac AAV9-S100A1 gene therapy rescues post-ischemic heart failure in a preclinical large animal model.Science translational medicine, 3 (92), 92ra64-92ra64.

Podesser, B. K., Schirnhofer, J., Bernecker, O. Y., Kroner, A., Franz, M., Semsroth, S., . . Wolner, E. (2002). Optimizing ischemia/reperfusion in the failing rat heart-improved myocardial protection with acute ACE inhibition. Circulation, 106 (12_suppl_1), I-277-I-283.

Reitz, C. J., Alibhai, F. J., Khatua, T. N., Rasouli, M., Bridle, B. W., Burris, T. P., \& Martino, T. A. (2019). SR9009 administered for one day after myocardial ischemia-reperfusion prevents heart failure in mice by targeting the cardiac inflammasome. Communications biology, 2 (1), 1-15. 
Riehle, C., \& Bauersachs, J. (2019). Small animal models of heart failure. Cardiovascular research, 115 (13), 1838-1849.

Sabbah, H. N., Stanley, W. C., Sharov, V. G., Mishima, T., Tanimura, M., Benedict, C. R., .. Goldstein, S. (2000). Effects of dopamine $\beta$-hydroxylase inhibition with nepicastat on the progression of left ventricular dysfunction and remodeling in dogs with chronic heart failure. Circulation, 102 (16), 1990-1995.

Sabbah, H. N., Stein, P. D., Kono, T., Gheorghiade, M., Levine, T. B., Jafri, S., .. Goldstein, S. (1991). A canine model of chronic heart failure produced by multiple sequential coronary microembolizations. American Journal of Physiology-Heart and Circulatory Physiology, 260 (4), H1379-H1384.

Saku, K., Kakino, T., Arimura, T., Sunagawa, G., Nishikawa, T., Sakamoto, T., ... Sunagawa, K. (2018). Left ventricular mechanical unloading by total support of Impella in myocardial infarction reduces infarct size, preserves left ventricular function, and prevents subsequent heart failure in dogs. Circulation: Heart Failure, 11 (5), e004397.

Santos-Gallego, C. G., Requena-Ibanez, J. A., San Antonio, R., Ishikawa, K., Watanabe, S., Picatoste, B., ... Hajjar, R. J. (2019). Empagliflozin ameliorates adverse left ventricular remodeling in nondiabetic heart failure by enhancing myocardial energetics.Journal of the American College of Cardiology, 73 (15), 1931-1944.

Sato, Y., Ferguson, D. G., Sako, H., Dorn II, G. W., Kadambi, V. J., Yatani, A., .. Kranias, E. G. (1998). Cardiac-specific overexpression of mouse cardiac calsequestrin is associated with depressed cardiovascular function and hypertrophy in transgenic mice.Journal of Biological Chemistry, 273 (43), 28470-28477.

Schneider, R. M., Chu, A., Akaishi, M., Weintraub, W., Morris, K., \& Cobb, F. (1985). Left ventricular ejection fraction after acute coronary occlusion in conscious dogs: relation to the extent and site of myocardial infarction. Circulation, 72 (3), 632-638.

Shannon, R. P., Komamura, K., Shen, Y. T., Bishop, S. P., \& Vatner, S. F. (1993). Impaired regional subendocardial coronary flow reserve in conscious dogs with pacing-induced heart failure. American Journal of Physiology-Heart and Circulatory Physiology, 265 (3), H801-H809.

Shen, Y.-T., Chen, L., Testani, J. M., Regan, C. P., \& Shannon, R. P. (2017). Animal Models for Cardiovascular Research. In Animal Models for the Study of Human Disease, (pp. 147-174): Elsevier.

Shen, Y. T., \& Vatner, S. F. (1996). Differences in myocardial stunning following coronary artery occlusion in conscious dogs, pigs, and baboons. American Journal of Physiology-Heart and Circulatory Physiology, 270 (4), H1312-H1322.

Shimizu, Y., Polavarapu, R., Eskla, K. L., Pantner, Y., Nicholson, C. K., Ishii, M., ... Naqvi, N. (2018). Impact of lymphangiogenesis on cardiac remodeling after ischemia and reperfusion injury. Journal of the American Heart Association, 7 (19), e009565.

Silva, K. A. S., \& Emter, C. A. (2020). Large Animal Models of Heart Failure: A Translational Bridge to Clinical Success. JACC: Basic to Translational Science, 5 (8), 840-856.

Spinale, F. G., de Gasparo, M., Whitebread, S., Hebbar, L., Clair, M. J., Melton, D. M., ... O, S.J. (1997). Modulation of the renin-angiotensin pathway through enzyme inhibition and specific receptor blockade in pacing-induced heart failure: I. Effects on left ventricular performance and neurohormonal systems. Circulation, 96 (7), 2385-2396.

Spinale, F. G., Ishihra, K., Zile, M., DeFryte, G., Crawford, F. A., \& Carabello, B. A. (1993). Structural basis for changes in left ventricular function and geometry because of chronic mitral regurgitation and after correction of volume overload. The Journal of thoracic and cardiovascular surgery, 106 (6), 1147-1157.

Tagawa, H., Koide, M., Sato, H., Zile, M. R., Carabello, B. A., \& Cooper IV, G. (1998). Cytoskeletal role in the transition from compensated to decompensated hypertrophy during adult canine left ventricular pressure 
overloading. Circulation research, 82 (7), 751-761.

Takagaki, M., McCarthy, P. M., Tabata, T., Dessoffy, R., Cardon, L. A., Connor, J., .. Young, J. B. (2002). Induction and maintenance of an experimental model of severe cardiomyopathy with a novel protocol of rapid ventricular pacing. The Journal of thoracic and cardiovascular surgery, 123 (3), 544-549.

Teerlink, J. R., Pfeffer, J. M., \& Pfeffer, M. A. (1994). Progressive ventricular remodeling in response to diffuse isoproterenol-induced myocardial necrosis in rats. Circulation research, 75 (1), 105-113.

Thygesen, K., Alpert, J. S., White, H. D., \& Infarction, J. E. A. A. W. T. F. f. t. R. o. M. (2007). Universal definition of myocardial infarction. Journal of the American College of Cardiology, 50 (22), 2173-2195.

Triposkiadis, F., Karayannis, G., Giamouzis, G., Skoularigis, J., Louridas, G., \& Butler, J. (2009). The sympathetic nervous system in heart failure: physiology, pathophysiology, and clinical implications. Journal of the American College of Cardiology, 54 (19), 1747-1762.

Turner, N., Haga, K. L., Else, P. L., \& Hulbert, A. (2006). Scaling of Na+, K+-ATPase molecular activity and membrane fatty acid composition in mammalian and avian hearts. Physiological and Biochemical Zoology, 79 (3), 522-533.

Uemura, N., Knight, D. R., Shen, Y., Nejima, J., Cohen, M. V., Thomas Jr, J. X., \& Vatner, S. F. (1989). Increased myocardial infarct size because of reduced coronary collateral blood flow in beagles.American Journal of Physiology-Heart and Circulatory Physiology, 257 (6), H1798-H1803.

van den Borne, S. W., van De Schans, V. A., Strzelecka, A. E., Vervoort-Peters, H. T., Lijnen, P. M., Cleutjens, J. P., .. Blankesteijn, W. M. (2009). Mouse strain determines the outcome of wound healing after myocardial infarction. Cardiovascular research, 84 (2), 273-282.

Van der Velden, J., Merkus, D., Klarenbeek, B., James, A., Boontje, N., Dekkers, D., .. Duncker, D. (2004). Alterations in myofilament function contribute to left ventricular dysfunction in pigs early after myocardial infarction. Circulation research, 95 (11), e85-e95.

Virani, S. S., Alonso, A., Benjamin, E. J., Bittencourt, M. S., Callaway, C. W., Carson, A. P., .. Delling, F. N. (2020). Heart disease and stroke statistics - 2020 update: a report from the American Heart Association. Circulation, 141 (9), e139-e596.

Westerhof, N., \& Elzinga, G. (1993). Why smaller animals have higher heart rates. In Interactive Phenomena in the Cardiac System, (pp. 319-323): Springer.

Wu, J. C., Nasseri, B. A., Bloch, K. D., Picard, M. H., \& Scherrer-Crosbie, M. (2003). Influence of sex on ventricular remodeling after myocardial infarction in mice. Journal of the American Society of Echocardiography, 16 (11), 1158-1162.

Yamamoto, R., Akazawa, H., Ito, K., Toko, H., Sano, M., Yasuda, N., .. Chien, K. R. (2007). Angiotensin II type 1a receptor signals are involved in the progression of heart failure in MLP-deficient mice.Circulation Journal, 71 (12), 1958-1964.

Yamori, Y. (1991). Overview: studies on spontaneous hypertension-development from animal models toward man. Clinical and Experimental Hypertension. Part A: Theory and Practice, 13 (5), 631-644.

Ye, Y., Gong, G., Ochiai, K., Liu, J., \& Zhang, J. (2001). High-energy phosphate metabolism and creatine kinase in failing hearts: a new porcine model. Circulation, 103 (11), 1570-1576.

Zhang, J., Wilke, N., Wang, Y., Zhang, Y., Wang, C., Eijgelshoven, M. H., .. Bache, R. J. (1996). Functional and bioenergetic consequences of postinfarction left ventricular remodeling in a new porcine model: MRI and 31P-MRS study. Circulation, 94 (5), 1089-1100.

Zhang, Y., Sun, Q., He, B., Xiao, J., Wang, Z., \& Sun, X. (2011). Anti-inflammatory effect of hydrogen-rich saline in a rat model of regional myocardial ischemia and reperfusion. International journal of cardiology, 
$148(1), 91-95$.

Zolotareva, A., \& Kogan, M. (1978). Production of experimental occlusive myocardial infarction in mice. Cor et vasa, 20 (4), 308-314.

Figure legends

Figure 1. Application of animal models commonly used for heart failure research. HF, heart failure; DCM, dilated cardiomyopathy. Recommended or not recommended HF stimulus are indicated by green tick marks or grey crosses marks, respectively.

Figure 2. Main strengths, weaknesses and applicability of pre-clinical models commonly used in heart failure research.

Figure 1

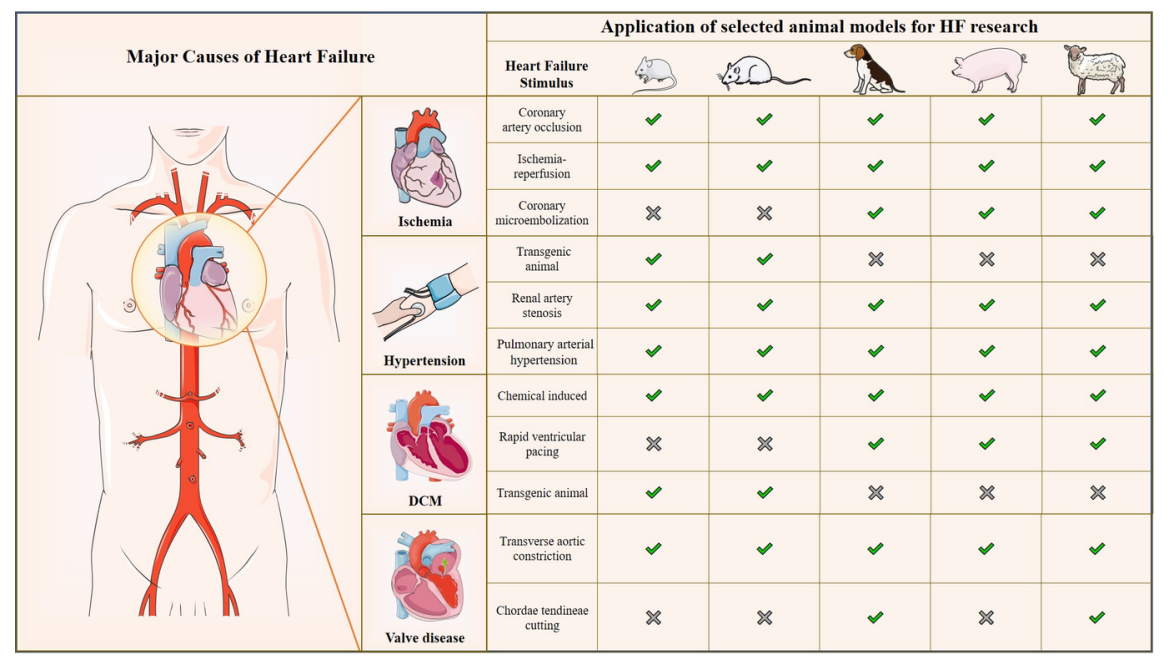

Figure 2
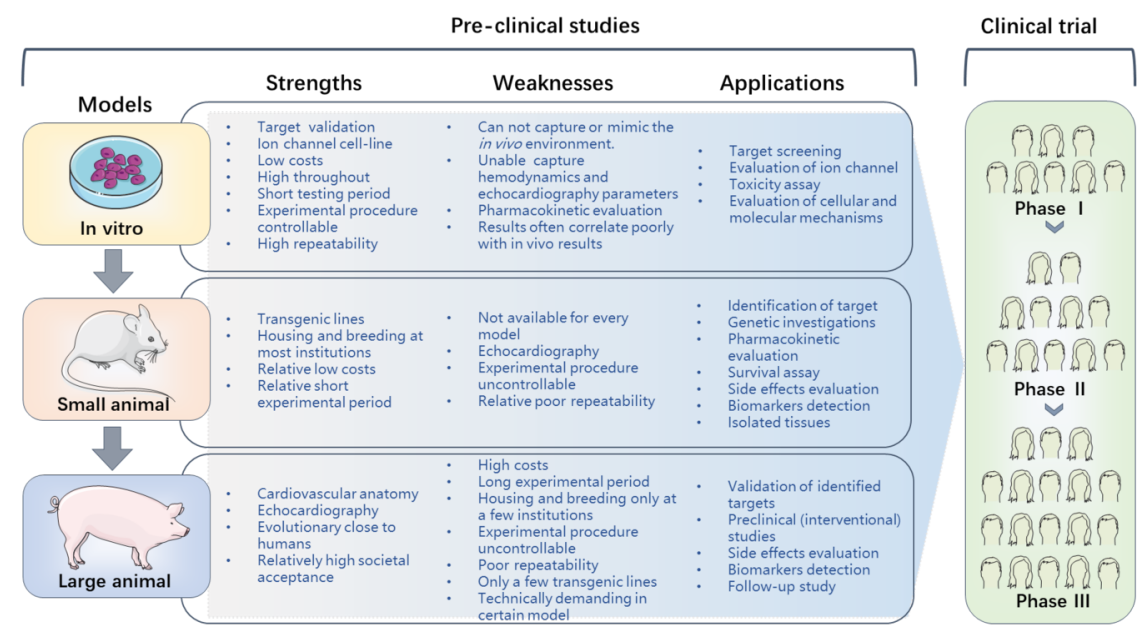

Table 1 Selected physiological and echocardiographic parameters of animal models and humans 


\begin{tabular}{|c|c|c|}
\hline Species & Mice $^{\text {abc }}$ & Rats $^{\text {bcd }}$ \\
\hline General & General & General \\
\hline Lifespan (year) & $1.5-3.0$ & $2.5-3.5$ \\
\hline Adult body mass (kg) & $0.02-0.03$ & $0.2-0.5$ \\
\hline Heart mass $(g)$ & $0.20-0.27$ & $0.62-0.68$ \\
\hline Body temperature () & $36.5-38.0$ & $35.9-37.5$ \\
\hline Haemodynamics & Haemodynamics & Haemodynamics \\
\hline Blood pressure (mmHg) & $120 / 71$ & $84-134 / 60$ \\
\hline Blood volume $(\mathrm{ml} / \mathrm{kg})$ & $70-80$ & $50-65$ \\
\hline Cardiac output (ml/min) & $16-24$ & $115-159$ \\
\hline Respiratory rate (breaths/min) & $60-120$ & $70-115$ \\
\hline Heart Rate (beats/min) & $300-800$ & $250-450$ \\
\hline Normal cardiac function parameters & Normal cardiac function parameters & Normal cardiac function para \\
\hline LVPSP $(\mathrm{mmHg})$ & $100-122$ & $124-159$ \\
\hline LVEDP (mmHg) & $2.0-5.2$ & $0-16$ \\
\hline $\mathrm{LV}+\mathrm{dP} / \mathrm{dt}(\mathrm{mmHg} / \mathrm{s})$ & $8,084-17,916$ & $1,600-4,500$ \\
\hline $\mathrm{LV}-\mathrm{d} P / \mathrm{d} t(\mathrm{mmHg} / \mathrm{s})$ & $6,282-14,136$ & $1,480-3,460$ \\
\hline $\operatorname{LVVS}(\mathrm{mm} / \mathrm{s})$ & $17-21$ & $21-112$ \\
\hline LVFS (\%) & $49-57$ & $52-59$ \\
\hline LVEDV (ml) or $(\mu \mathrm{l})$ & $15.4-65.0$ & $160-180$ \\
\hline $\mathrm{SV}(\mathrm{ml})$ or $(\mathrm{ml})$ & $10.0-14.4$ & $150-200$ \\
\hline
\end{tabular}

a-i: Modified from subset of data summarized in references (Alhumaidha, Saleh, Abd El Fattah, El-Eraky, \& Moawad, 2016; Clauss et al., 2019; Cotton et al., 2001; Gross, 2009; Hau \& Schapiro, 2002; KE, Brooks, \& Warbaase, 1974; Matsuda et al., 1983; Pilla et al., 2003; Turner, Haga, Else, \& Hulbert, 2006). LVPSP, left ventricular peak systolic pressure; LVEDP, left ventricular end-diastolic pressure; LV $+\mathrm{dP} / \mathrm{d} t$, left ventricular $+\mathrm{d} \mathrm{P} / \mathrm{d}$ t; $\mathrm{LV}-\mathrm{dP} / \mathrm{d}$ t, left ventricular $-\mathrm{d} \mathrm{P} / \mathrm{d} t$, LVVS, left ventricular velocity of shortening; LVFS, left ventricular fractional shortening; LVEDV, left ventricular end-diastolic volume; SV, stroke volume.

Table 2 Characteristics of selected animal models commonly used for HF research. 


\begin{tabular}{|c|c|c|c|c|c|c|}
\hline $\begin{array}{l}\text { Major } \\
\text { causes of } \\
\text { HF }\end{array}$ & Model & $\begin{array}{l}\text { Heart } \\
\text { Failure } \\
\text { Stimulus }\end{array}$ & $\begin{array}{l}\text { Pathology } \\
\text { feature }\end{array}$ & Limitation & Species & $\begin{array}{l}\text { Selected } \\
\text { references }\end{array}$ \\
\hline $\begin{array}{l}\text { Major } \\
\text { causes of } \\
\text { HF }\end{array}$ & Model & $\begin{array}{l}\text { Heart } \\
\text { Failure } \\
\text { Stimulus }\end{array}$ & $\begin{array}{l}\text { Pathology } \\
\text { feature }\end{array}$ & Limitation & Species & $\begin{array}{l}\text { Selected } \\
\text { references }\end{array}$ \\
\hline Ischemia & $\begin{array}{l}\text { Myocardial } \\
\text { infarct }\end{array}$ & $\begin{array}{l}\text { Permanent left } \\
\text { coronary } \\
\text { artery } \\
\text { occlusion }\end{array}$ & $\begin{array}{l}\text { LVEDD - } \\
\text { LVESD - }, \text { FS } \\
-, \text { LV systolic } \\
\text { pressure - } \\
\text { dP/dtmax - } \\
\text { dP/dtmin - }\end{array}$ & $\begin{array}{l}\text { 1. Model does } \\
\text { not reflect the } \\
\text { clinical setting } \\
\text { with } \\
\text { reperfusion of } \\
\text { the occluded } \\
\text { vessel during } \\
\text { coronary } \\
\text { angiography } \\
\text { performed } \\
\text { after an acute } \\
\text { MI. } 2 . \\
\text { Expense of } \\
\text { equipment for } \\
\text { cardiovascular } \\
\text { physiology } \\
\text { assessment. }\end{array}$ & Mouse & $\begin{array}{l}\text { (Gao et al., } \\
2000)\end{array}$ \\
\hline & & & $\begin{array}{l}\text { LV systolic } \\
\text { function -, } \\
\text { LVEDV - } \\
\text { PRA - } \\
\text { arginine } \\
\text { vasopressin } \\
\text {-, atrial } \\
\text { natriuretic } \\
\text { factor - }\end{array}$ & & Rat & $\begin{array}{l}\text { (Francis, } \\
\text { Weiss, Wei, } \\
\text { Johnson, \& } \\
\text { Felder, } \\
\text { 2001) }\end{array}$ \\
\hline
\end{tabular}




\begin{tabular}{|c|c|c|c|c|c|c|}
\hline \multirow[t]{4}{*}{$\begin{array}{l}\text { Major } \\
\text { causes of } \\
\text { HF }\end{array}$} & \multirow[t]{2}{*}{ Model } & $\begin{array}{l}\text { Heart } \\
\text { Failure } \\
\text { Stimulus }\end{array}$ & $\begin{array}{l}\text { Pathology } \\
\text { feature }\end{array}$ & \multirow[t]{2}{*}{ Limitation } & Species & $\begin{array}{l}\text { Selected } \\
\text { references }\end{array}$ \\
\hline & & $\begin{array}{l}\text { Permanent } \\
\text { coronary } \\
\text { occlusion in } \\
\text { the left } \\
\text { anterior } \\
\text { descending } \\
\text { coronary } \\
\text { artery (LAD) } \\
\text { or left } \\
\text { circumflex } \\
\text { coronary } \\
\text { artery (LCx) } \\
\text { by acute } \\
\text { ligation, or } \\
\text { thrombogenic } \\
\text { coil, hydraulic } \\
\text { occluder and } \\
\text { ameroid } \\
\text { constrictor } \\
\text { placement. }\end{array}$ & $\begin{array}{l}\text { LVEF -, } \\
\text { MAP -, } \\
\text { LVSP - , } \\
\text { LVEDP - }\end{array}$ & & Dog & $\begin{array}{l}\text { (Schneider et } \\
\text { al., 1985) } \\
\text { (Ferrarini et } \\
\text { al., 2006) }\end{array}$ \\
\hline & & & $\begin{array}{l}\text { LVEF -, } \\
\text { LV volumes } \\
-, \text { BNP, } \\
\text { NT-proBNP } \\
\text { and cGMP } \\
-\end{array}$ & & Sheep & $\begin{array}{l}\text { (Charles, } \\
\text { Elliott, } \\
\text { Nicholls, } \\
\text { Rademaker, } \\
\text { \& Richards, } \\
\text { 2003) }\end{array}$ \\
\hline & & & $\begin{array}{l}\text { LV weight } \\
-, \text { LV } \\
\text { end-diastolic } \\
\text { area -, EF } \\
-, \\
\text { Endogenous } \\
\text { protein } \\
\text { kinase A-, } \\
\text { SERCA2a-, } \\
\text { TnI-, } \\
\text { Ca2+ } \\
\text { sensitivity of } \\
\text { force } \\
\text { (pCa50) - }\end{array}$ & & Pig & $\begin{array}{l}\text { (Van der } \\
\text { Velden et } \\
\text { al., 2004) }\end{array}$ \\
\hline
\end{tabular}




\begin{tabular}{|c|c|c|c|c|c|c|}
\hline $\begin{array}{l}\text { Major } \\
\text { causes of } \\
\text { HF }\end{array}$ & $\begin{array}{l}\text { Model } \\
\begin{array}{l}\text { Ischemia- } \\
\text { reperfusion }\end{array}\end{array}$ & $\begin{array}{l}\text { Heart } \\
\text { Failure } \\
\text { Stimulus }\end{array}$ & $\begin{array}{l}\text { Pathology } \\
\text { feature }\end{array}$ & Limitation & Species & $\begin{array}{l}\text { Selected } \\
\text { references }\end{array}$ \\
\hline & $\begin{array}{l}\text { Ischemia- } \\
\text { reperfusion }\end{array}$ & $\begin{array}{l}\text { LAD } \\
\text { occlusion for } \\
30-60 \text { min } \\
\text { followed by } \\
\text { reperfusion } \\
\text { allowing flow } \\
\text { through the } \\
\text { previously } \\
\text { occluded } \\
\text { coronary } \\
\text { artery bed. }\end{array}$ & $\begin{array}{l}\text { LVIDd-, } \\
\text { LVIDs -, } \\
\text { EF -, FS } \\
-, \text { HR -, } \\
\text { LVESP -, } \\
\text { LVESV-, } \\
\text { LVEDV - } \\
\text { SV -, CO } \\
-, \\
+\mathrm{dP} / \mathrm{dtmax} \\
-, \\
-\mathrm{dP} / \mathrm{dtmin} \\
-, \mathrm{SBP}-\text {, } \\
\mathrm{HW}-\text {, } \\
\mathrm{HW} / \mathrm{BW}-\end{array}$ & $\begin{array}{l}\text { 1. Surgery is } \\
\text { time } \\
\text { consuming } \\
\text { and complex } \\
\text { than } \\
\text { placement of } \\
\text { permanent } \\
\text { LAD } \\
\text { ligation }\end{array}$ & Mouse & $\begin{array}{l}\text { (Reitz et al., } \\
2019 \text { ) }\end{array}$ \\
\hline & & & $\begin{array}{l}\text { LVSP-, } \\
\text { LVEDP - , } \\
+\mathrm{dP} / \text { dtmax } \\
-, \\
-\mathrm{dP} / \text { dtmax }\end{array}$ & & Rat & $\begin{array}{l}\text { (Y. Zhang et } \\
\text { al., 2011) }\end{array}$ \\
\hline & & $\begin{array}{l}\text { LAD or LCx } \\
\text { occlu- } \\
\text { sion/reperfusion } \\
\text { by PTCA } \\
\text { balloon }\end{array}$ & $\begin{array}{l}\text { LV } \\
\text { end-diastolic } \\
\text { pressure - , } \\
\text { LV } \\
\text { end-systolic } \\
\text { elastance - } \\
\text { NT-proBNP } \\
\text { level - }\end{array}$ & & Dog & $\begin{array}{l}\text { (Saku et al., } \\
2018 \text { ) }\end{array}$ \\
\hline & & & $\begin{array}{l}\text { Creatine } \\
\text { kinase - } \\
\text { Troponin-T } \\
-, \text { EF - } \\
\text { FS - }\end{array}$ & & Sheep & $\begin{array}{l}\text { (CHARLES } \\
\text { et al., 2000) }\end{array}$ \\
\hline & & & $\begin{array}{l}\text { EF -, LV } \\
+ \text { dp/dt -, } \\
\text { LVEDD -, } \\
\text { LV } \\
\text { hypertrophy } \\
\text { HW /BW - }\end{array}$ & & Pig & $\begin{array}{l}\text { (Pleger et } \\
\text { al., 2011) }\end{array}$ \\
\hline
\end{tabular}




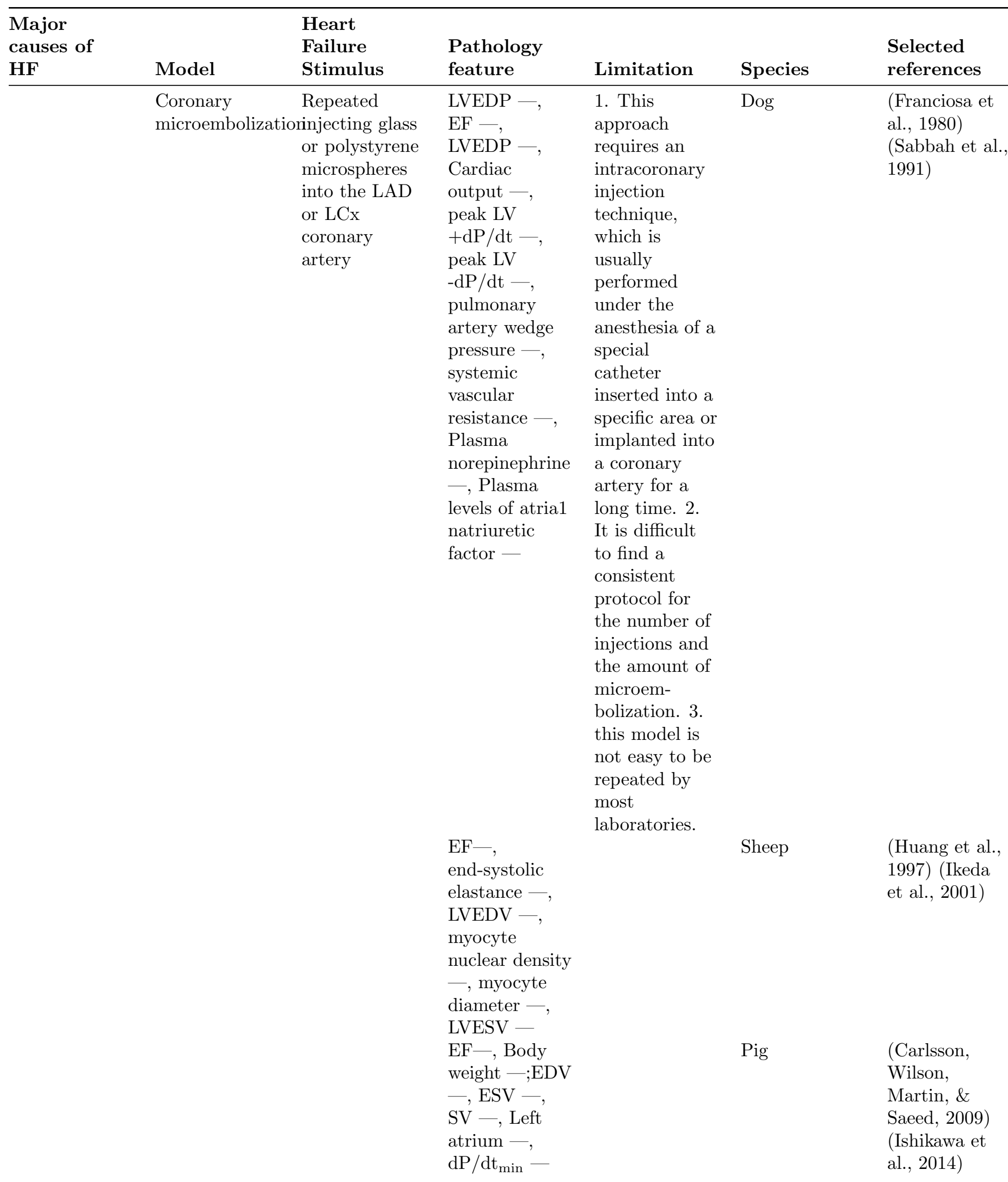




\begin{tabular}{|c|c|c|c|c|c|c|}
\hline $\begin{array}{l}\text { Major } \\
\text { causes of } \\
\text { HF }\end{array}$ & Model & $\begin{array}{l}\text { Heart } \\
\text { Failure } \\
\text { Stimulus }\end{array}$ & $\begin{array}{l}\text { Pathology } \\
\text { feature }\end{array}$ & Limitation & Species & $\begin{array}{l}\text { Selected } \\
\text { references }\end{array}$ \\
\hline \multirow[t]{4}{*}{ Hypertension } & $\begin{array}{l}\text { Transgenic } \\
\text { lines }\end{array}$ & $\begin{array}{l}\text { Spontaneously } \\
\text { hypertensive } \\
\text { rat }\end{array}$ & $\begin{array}{l}\text { myocardial } \\
\text { fibrosis -; } \\
\text { passive } \\
\text { stiffness-, } \\
\text { LV collagen } \\
\text { concentra- } \\
\text { tion-- } \\
\text { contractile } \\
\text { function- }\end{array}$ & $\begin{array}{l}1 . \\
\text { Limitations } \\
\text { of small } \\
\text { animal } \\
\text { species in } \\
\text { terms of } \\
\text { comprehen- } \\
\text { sive } \\
\text { physiological } \\
\text { measurement }\end{array}$ & Rat & $\begin{array}{l}\text { (Conrad et } \\
\text { al., 1995) }\end{array}$ \\
\hline & & $\begin{array}{l}\text { Spontaneously } \\
\text { hypertensive } \\
\text { HF rat }\end{array}$ & $\begin{array}{l}\text { RWT -, } \\
\text { LVEDV -, } \\
\text { LVESV -, } \\
\text { LVAd -, } \\
\text { LVAs -, EF } \\
-, \text { FS -, } \\
\text { E-vel -, } \\
\text { A-vel -, IR } \\
-, \text { LVLd - , } \\
\text { LVM -, } \\
\text { LVIDd -, } \\
\text { LVIDs -, } \\
\text { SV- }\end{array}$ & & Rat & $\begin{array}{l}\text { (Heyen et } \\
\text { al., 2002) }\end{array}$ \\
\hline & & $\begin{array}{l}\text { Dahl-salt- } \\
\text { sensitive } \\
\text { rat }\end{array}$ & $\begin{array}{l}\text { SWT -, } \\
\text { LVEDP -, } \\
\text { LVESD - } \\
\text { EF - FS } \\
-, \text { ESV -, } \\
\text { Tau- }\end{array}$ & & Rat & $\begin{array}{l}\text { (Klotz et al., } \\
2006)\end{array}$ \\
\hline & $\begin{array}{l}\text { Renal artery } \\
\text { stenosis }\end{array}$ & $\begin{array}{l}\text { Goldblatt } \\
\text { Hyperten- } \\
\text { sion method, } \\
\text { including } \\
\text { Two-kidney, } \\
\text { one clip } \\
{[2 \mathrm{~K} 1 \mathrm{C}] \text { and }} \\
\text { one-kidney, } \\
\text { one clip } \\
\text { [1K1C] } \\
\text { hypertension }\end{array}$ & $\begin{array}{l}\text { Systolic } \\
\text { blood } \\
\text { pressure -, } \\
\text { HW/BW -, } \\
\text { LVDd -, } \\
\text { LVPWd -, } \\
\text { LVM -, } \\
\mathrm{LVM/BW} \\
-, \mathrm{Ea} / \mathrm{Aa}, \\
\mathrm{E} / \mathrm{Ea}-, \\
\mathrm{dp} / \mathrm{dt}_{\text {min }}- \\
\mathrm{Tau}-\end{array}$ & $\begin{array}{l}1 . \\
\text { Unspecific } \\
\text { side effects } \\
\text { on organ } \\
\text { systems, } \\
\text { especially } \\
\text { kidney. }\end{array}$ & Rat & $\begin{array}{l}\text { (Junhong et } \\
\text { al., 2008) }\end{array}$ \\
\hline
\end{tabular}




\begin{tabular}{|c|c|c|c|c|c|c|}
\hline $\begin{array}{l}\text { Major } \\
\text { causes of } \\
\text { HF }\end{array}$ & Model & $\begin{array}{l}\text { Heart } \\
\text { Failure } \\
\text { Stimulus }\end{array}$ & $\begin{array}{l}\text { Pathology } \\
\text { feature }\end{array}$ & Limitation & Species & $\begin{array}{l}\text { Selected } \\
\text { references }\end{array}$ \\
\hline \multirow{4}{*}{ DCM } & \multirow{4}{*}{$\begin{array}{l}\text { Chemical } \\
\text { induced }\end{array}$} & $\begin{array}{l}\text { Page model, } \\
\text { which can } \\
\text { be produced } \\
\text { by wrapping } \\
\text { one or both } \\
\text { kidneys in } \\
\text { cellophane }\end{array}$ & $\begin{array}{l}\mathrm{SBP}-, \\
\mathrm{DBP}-\text {-, } \\
\text { MAP - } \\
\text { arterial } \\
\text { BPs-, PP } \\
-, \\
\text { LVM/BW } \\
-, \text { Fibrosis } \\
-, \text { Tau -, } \\
\text { End-systolic } \\
\text { LV } \\
\text { stiffness- }\end{array}$ & \multirow{4}{*}{$\begin{array}{l}\text { 1. Variability } \\
\text { of response to } \\
\text { chemicals, the } \\
\text { degree of LV } \\
\text { dysfunction } 2 \text {. } \\
\text { animal } \\
\text { mortality } \\
\text { caused by } \\
\text { arrhythmia, } \\
\text { and engenders } \\
\text { several } \\
\text { systemic side } \\
\text { effects, such as } \\
\text { bone marrow } \\
\text { suppression, } \\
\text { gastrointesti- } \\
\text { nal } \\
\text { discomfort. }\end{array}$} & Dog & $\begin{array}{l}\text { (Munagala } \\
\text { et al., 2005) }\end{array}$ \\
\hline & & \multirow[t]{3}{*}{$\begin{array}{l}\text { Intracoronary } \\
\text { adriamycin or } \\
\text { isoprenaline }\end{array}$} & $\begin{array}{l}\text { AWT -, } \\
\text { PWT - , } \\
\text { LVEDD -, } \\
\text { LVESD -, } \\
\text { LVM/BW -, } \\
\text { FS -, PAV } \\
-, \text { VCDc -, } \\
\text { SBP-, } \\
\text { MABP -, } \\
\text { LVEDP -, } \\
+ \text { dP/dtmax } \\
-,-d P / d t m i n \\
-\end{array}$ & & Mouse & $\begin{array}{l}\text { (Oudit et al. } \\
2003 \text { ) }\end{array}$ \\
\hline & & & $\begin{array}{l}\text { LVEDP -, } \\
\text { volume } \\
\text { indexes - , } \\
\text { global } \\
\text { diastolic } \\
\text { wall stress } \\
-\end{array}$ & & Rat & $\begin{array}{l}\text { (Teerlink, } \\
\text { Pfeffer, \& } \\
\text { Pfeffer, } \\
\text { 1994) }\end{array}$ \\
\hline & & & $\begin{array}{l}\text { EF -, } \\
\text { LVEED -, } \\
\text { LVESD -, } \\
\text { LVESV -, } \\
\text { E septal } \\
\text { point - , } \\
\text { Aprtic } \\
\text { velocity - } \\
\text { IVRT - }\end{array}$ & & Dog & $\begin{array}{l}\text { (Monnet \& } \\
\text { Orton, 1999) }\end{array}$ \\
\hline
\end{tabular}




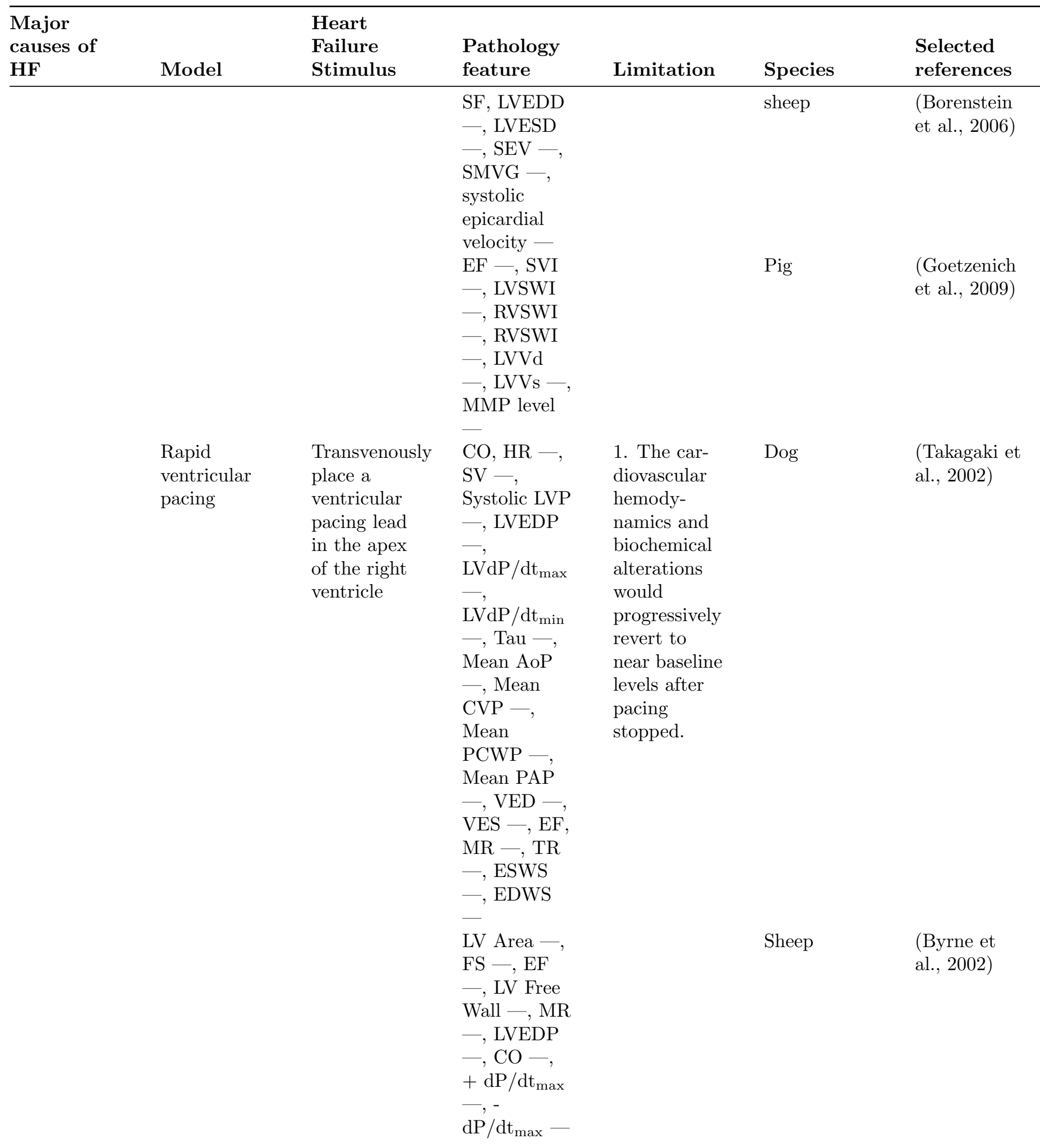




\begin{tabular}{|c|c|c|c|c|c|c|}
\hline $\begin{array}{l}\text { Major } \\
\text { causes of } \\
\text { HF }\end{array}$ & Model & $\begin{array}{l}\text { Heart } \\
\text { Failure } \\
\text { Stimulus }\end{array}$ & $\begin{array}{l}\text { Pathology } \\
\text { feature }\end{array}$ & Limitation & Species & $\begin{array}{l}\text { Selected } \\
\text { references }\end{array}$ \\
\hline & \multirow{3}{*}{$\begin{array}{l}\text { Transgenic } \\
\text { lines }\end{array}$} & & $\begin{array}{l}\text { HR -, } \\
\text { MAP, } \\
\text { LVEDD -, } \\
\text { FS -, Vcfc } \\
-, \text { LV peak } \\
\text { wall stress } \\
-, \text { PCWP } \\
-, \text { PAP - } \\
\text { CO - }\end{array}$ & \multirow{3}{*}{$\begin{array}{l}1 . \\
\text { Limitations } \\
\text { of small } \\
\text { animal } \\
\text { species in } \\
\text { terms of } \\
\text { comprehen- } \\
\text { sive } \\
\text { physiological } \\
\text { measurement }\end{array}$} & Pig & $\begin{array}{l}\text { (Spinale et } \\
\text { al., 1997) }\end{array}$ \\
\hline & & $\begin{array}{l}\text { MLP- } \\
\text { deficient } \\
\text { mice }\end{array}$ & $\begin{array}{l}\text { LVDD -, } \\
\text { LVSD -, } \\
\text { FS -, } \\
\text { LVDD/LVPWT } \\
-\end{array}$ & & Mouse & $\begin{array}{l}\text { (Yamamoto } \\
\text { et al., 2007) }\end{array}$ \\
\hline & & CSQ mice & $\begin{array}{l}\text { LVEDD -, } \\
\text { LVESD -, } \\
\text { FS -, } \\
\text { mVcfc -, } \\
\mathrm{HW} / \mathrm{BW}-\text {, } \\
\mathrm{LVW} / \mathrm{BW} \\
-, \mathrm{HW} / \mathrm{TL} \\
-, \mathrm{HR}, \mathrm{LV} \\
\mathrm{dP} / \mathrm{dtmax} \\
-, \mathrm{LV} \\
\mathrm{dP} / \mathrm{dtmin} \\
-, \mathrm{LVSP}-\end{array}$ & & Mouse & $\begin{array}{l}\text { (Cho et al., } \\
1999)\end{array}$ \\
\hline
\end{tabular}




\begin{tabular}{|c|c|c|c|c|c|c|}
\hline $\begin{array}{l}\text { Major } \\
\text { causes of } \\
\text { HF }\end{array}$ & Model & $\begin{array}{l}\text { Heart } \\
\text { Failure } \\
\text { Stimulus }\end{array}$ & $\begin{array}{l}\text { Pathology } \\
\text { feature }\end{array}$ & Limitation & Species & $\begin{array}{l}\text { Selected } \\
\text { references }\end{array}$ \\
\hline \multirow[t]{4}{*}{ Valve disease } & Aortic stenosis & $\begin{array}{l}\text { Several } \\
\text { surgical } \\
\text { techniques, } \\
\text { including a } \\
\text { minimally } \\
\text { invasive } \\
\text { approach by } \\
\text { making a small } \\
\text { incision in the } \\
\text { proximal } \\
\text { sternum, and } \\
\text { placement of } \\
\text { surgical clips, } \\
\text { sutures, or } \\
\text { O-rings to } \\
\text { prevent blood } \\
\text { flow through } \\
\text { the aortic arch }\end{array}$ & $\begin{array}{l}\text { EF - } \\
\text { LVEDV -, } \\
\text { LVEDD - }\end{array}$ & $\begin{array}{l}\text { 1. Inability to } \\
\text { easily induce } \\
\text { slowly } \\
\text { progressive } \\
\text { stress overload } \\
2 \text {. long } \\
\text { duration of the } \\
\text { experimental } \\
\text { protocol, } \\
\text { variability in } \\
\text { the individual } \\
\text { response to } \\
\text { stress } \\
\text { overload, and } \\
\text { a reduction in } \\
\text { the high } \\
\text { proportion of } \\
\text { constriction } \\
\text { due to } \\
\text { internalization } \\
\text { of the } \\
\text { contractile } \\
\text { knot. 3. High } \\
\text { mortality }\end{array}$ & Mouse & $\begin{array}{l}\text { (Li et al., } \\
2012 \text { ) }\end{array}$ \\
\hline & & & $\begin{array}{l}\text { LVSP -, } \\
\text { LVEDP -, } \\
\text { LVSWS - } \\
\text { LVDWS } \\
\text {-,PWD, } \\
\text { PWS } \\
\text {-,LVDD } \\
\text {-, LVSD } \\
\text {-, LVM -, } \\
\text { RWT - }\end{array}$ & & Rat & $\begin{array}{l}\text { (Litwin et } \\
\text { al., 1995) }\end{array}$ \\
\hline & & & $\begin{array}{l}\text { LVEDP - } \\
\text { LVEDV - } \\
\text { EF - }\end{array}$ & & Dog & $\begin{array}{l}\text { (Tagawa et } \\
\text { al., 1998) }\end{array}$ \\
\hline & & & $\begin{array}{l}\text { LVMI -, } \\
\text { LVIDd - } \\
\text { FS - }\end{array}$ & & Sheep & $\begin{array}{l}\text { (Moorjani et } \\
\text { al., 2006) }\end{array}$ \\
\hline
\end{tabular}




\begin{tabular}{|c|c|c|c|c|c|c|}
\hline $\begin{array}{l}\text { Major } \\
\text { causes of } \\
\text { HF }\end{array}$ & Model & $\begin{array}{l}\text { Heart } \\
\text { Failure } \\
\text { Stimulus }\end{array}$ & $\begin{array}{l}\text { Pathology } \\
\text { feature }\end{array}$ & Limitation & Species & $\begin{array}{l}\text { Selected } \\
\text { references }\end{array}$ \\
\hline & \multirow{4}{*}{$\begin{array}{l}\text { Mitral } \\
\text { regurgitation }\end{array}$} & \multirow{3}{*}{$\begin{array}{l}\text { Chordae } \\
\text { tendineae } \\
\text { cutting }\end{array}$} & $\begin{array}{l}\text { LVW - , } \\
\text { RVW -, } \\
\text { LVW/BW } \\
-, \\
\text { RVW/BW } \\
-, \text { LVEDP } \\
-, \\
\text { Myocardial } \\
\text { PCr/ATP } \\
\text { Ratio- }\end{array}$ & $\begin{array}{l}\text { 1. Complex } \\
\text { surgical } \\
\text { method and } \\
\text { equipment } \\
\text { necessary for } \\
\text { open-chest } \\
\text { microsurgery. }\end{array}$ & Pig & $\begin{array}{l}\text { (Ye et al., } \\
2001 \text { ) }\end{array}$ \\
\hline & & & $\begin{array}{l}\mathrm{HR}-\text {, } \\
\text { Aortic } \\
\text { systolic } \\
\text { pressure, } \\
\text { Forward } \\
\text { stroke } \\
\text { volume, } \\
\text { EDV-, } \mathrm{E}_{\mathrm{es}} \\
\text {-, E } \mathrm{E}_{\mathrm{es}} \\
\text { mass-, } \mathrm{K}_{\mathrm{ess}} \\
-,\end{array}$ & \multirow[t]{2}{*}{$\begin{array}{l}\text { 1. High } \\
\text { mortality } \\
\text { and } \\
\text { complication } \\
\text { rates }\end{array}$} & Dog & $\begin{array}{l}\text { (Spinale et } \\
\text { al., 1993) }\end{array}$ \\
\hline & & & $\begin{array}{l}\text { LV pressure } \\
-,+\mathrm{dP} / \mathrm{dt} \\
-, \mathrm{LVEDV} \\
-, \mathrm{E}_{\mathrm{es}}- \\
\text { PRSW- }\end{array}$ & & Sheep & $\begin{array}{l}\text { (Nielsen et } \\
\text { al., 2003) }\end{array}$ \\
\hline & & $\begin{array}{l}\text { Inserted a } \\
\text { fine needle } \\
\text { into LV } \\
\text { through the } \\
\text { apex of LV, } \\
\text { followed by } \\
\text { pushing a } \\
\text { needle into } \\
\text { the mitral } \\
\text { valve to } \\
\text { puncture } \\
\text { and/or tear } \\
\text { the mitral } \\
\text { leaflets to } \\
\text { form MR. }\end{array}$ & $\begin{array}{l}\mathrm{EF}-\text { EDD } \\
\frac{\mathrm{EWT}-\mathrm{SWT}}{\mathrm{PWT}-}\end{array}$ & $\begin{array}{l}\text { 1. Represent } \\
\text { limited } \\
\text { pathology } \\
\text { features of } \\
\text { MR in } \\
\text { human }\end{array}$ & Rat & $\begin{array}{l}\text { (Kim et al., } \\
2012 \text { ) }\end{array}$ \\
\hline
\end{tabular}

Up arrows (-) and down arrows (-) indicate an increase and decrease significant change of hemodynamics and echocardiography derived parameters in each animal model, respectively. LAD, left anterior descending coronary artery; LCx, left circumflex coronary artery; PTCA, percutaneous transluminal coronary angioplasty; TnI, troponin I; BNP, brain natriuretic peptide; NT-proBNP, N-terminal pro-B-type natriuretic peptide; PRA, Plasma renin activity; LV, left ventricular; LVIDd, LV internal dimensions at diastole; LVIDs, 
LV internal dimensions at systole; EF, ejection fraction; FS, fractional shortening; HR, heart rate; ESP, end systolic pressure; SV, stroke volume; $\mathrm{CO}$, cardiac output; $\mathrm{dP} / \mathrm{dtmax}$ and $\mathrm{dP} / \mathrm{dtmin}$, maximum and minimum first derivative of LV pressure; SBP, systolic blood pressure; DBP, diastolic blood pressure; MAP, mean arterial pressure; PP, pulse pressure; HW, heart weight; BW, body weight; EDV, end-diastolic volume; ESV, end-systolic volume; EDP, end-diastolic pressure; Tau, The time constant of isovolumic relaxation; IVRT, isovolumetric relaxation time; SEV, systolic endocardial velocity; SMVG, systolic myocardial velocity gradients; LVAd, LV area diastole; LVAs, LV area systole; E-vel, early filling velocity; A-Vel, late filling velocity; IR, isovolumetric relaxation time; LVLd, LV length diastole; LVM, LV mass; LVPWd, LV posterior wall diastole; MR, mitral valve regurgitation; PAP, pulmonary artery pressure, SWT, end-diastolic wall thickness of interventricular septum; $\mathrm{E}_{\mathrm{es}}$, Slope of end-systolic pressure-volume relation; $\mathrm{K}_{\mathrm{ess}}$, End-systolic stiffness constant; LVSP, LV systolic pressure; Ees, end-systolic elastance; PRSW, preload-recruitable stroke work; AWT, anterior wall thickness; PWT, posterior wall thickness; LVEDD, left ventricular end diastolic diameter; LVESD, left ventricular end systolic diameter; PAV, peak aortic velocity; VCFc, velocity of circumferential shortening corrected for heart rate; MABP, mean arterial blood pressure; AoP, Aortic pressure; CVP, central venous pressure; EDWS, end-diastolic wall stress; ESWS, end-systolic wall stress; LVEDP, left ventricular enddiastolic pressure; PCWP, pulmonary capillary wedge pressure; PVR, pulmonar vascular resistance; TR, tricuspid regurgitation; VED, end-diastolic volume; VES, end-systolic volume.

Table 3 Experiment models used in pre-clinical studies of selected approved drug for treatment of $\mathbf{H F}$ 


\begin{tabular}{|c|c|c|c|c|}
\hline $\begin{array}{l}\text { approval- } \\
\text { date }\end{array}$ & Target & $\begin{array}{l}\text { In vitro } \\
\text { studies }\end{array}$ & $\begin{array}{l}\text { In vivo } \\
\text { studies }\end{array}$ & Reference \\
\hline $\begin{array}{l}\text { Sacubitril/Valsartan2015 } \\
\text { Sodium Hydrate }\end{array}$ & AT1; NEP & $\begin{array}{l}\text { Recombinant } \\
\text { protein, NEP } \\
\text { and NEP-2 } \\
\text { enzyme activity } \\
\text { assay. Rat } \\
\text { cardiac } \\
\text { fibroblasts, } \\
\text { anti-fibrotic } \\
\text { effects. Rat } \\
\text { cardiomyocytes, } \\
\text { anti- } \\
\text { hypertrophic } \\
\text { effect. Rat and } \\
\text { human renal } \\
\text { cortex tissue, } \\
\text { NEP activity. }\end{array}$ & $\begin{array}{l}\text { Conscious rats, } \\
\text { effect on ANP } \\
\text { potentiation; } \\
\text { evaluation of } \\
\text { changes of } \\
\text { markers both the } \\
\text { RAAS and the } \\
\text { NP system; } \\
\text { Bradykinin } \\
\text { action. } \\
\text { Conscious dogs, } \\
\text { effect on ANP } \\
\text { potentiation; } \\
\text { evaluation of } \\
\text { changes of } \\
\text { markers of both } \\
\text { the RAAS and } \\
\text { the NP system; } \\
\text { cGMP. SHRSP, } \\
\text { effect on vascular } \\
\text { remodeling and } \\
\text { cardiac fibrosis, } \\
\text { cardiac arteriole } \\
\text { size, collagen } \\
\text { deposltion, and } \\
\text { MMP-2 activity. } \\
\text { Dahl } \\
\text { Salt-Sensitive } \\
\text { rat, effect on } \\
\text { left-ventricular } \\
\text { wheight; diuresis } \\
\text { blood pressure. } \\
\text { and natriuresis; } \\
\text { blood pressure; } \\
\text { renal function; } \\
\text { urinary cGMP. } \\
\text { MI rat models, } \\
\text { Cardiac } \\
\text { remodeling. } \\
\text { Double- } \\
\text { transgenic rat, } \\
\text { prect on blood } \\
\text { ratect on } \\
\text { Dloded }\end{array}$ & $\begin{array}{l}\text { FDA reviews: } \\
\text { 2076200rig1s000 }\end{array}$ \\
\hline
\end{tabular}




\begin{tabular}{|c|c|c|c|c|c|}
\hline Drug & $\begin{array}{l}\text { approval- } \\
\text { date }\end{array}$ & Target & $\begin{array}{l}\text { In vitro } \\
\text { studies }\end{array}$ & $\begin{array}{l}\text { In vivo } \\
\text { studies }\end{array}$ & Reference \\
\hline Macitentan & 2013 & $\begin{array}{l}\text { Tissue-targeting } \\
\text { dual endothelin } \\
\text { receptor }\end{array}$ & $\begin{array}{l}\text { ETA and ETB, } \\
\text { receptors stably } \\
\text { expressed CHO } \\
\text { cell, binding } \\
\text { assays; effect on } \\
\text { intracellular } \\
\text { calcium. Isolated } \\
\text { rat aorta and } \\
\text { trachea, } \\
\text { inhibition of } \\
\text { ET-1- induced } \\
\text { contraction in } \\
\text { isolated tissues. } \\
\text { Pulmonary } \\
\text { arterial smooth } \\
\text { muscle cells, } \\
\text { inhibitory } \\
\text { potency and } \\
\text { dissociation } \\
\text { kinetics. }\end{array}$ & 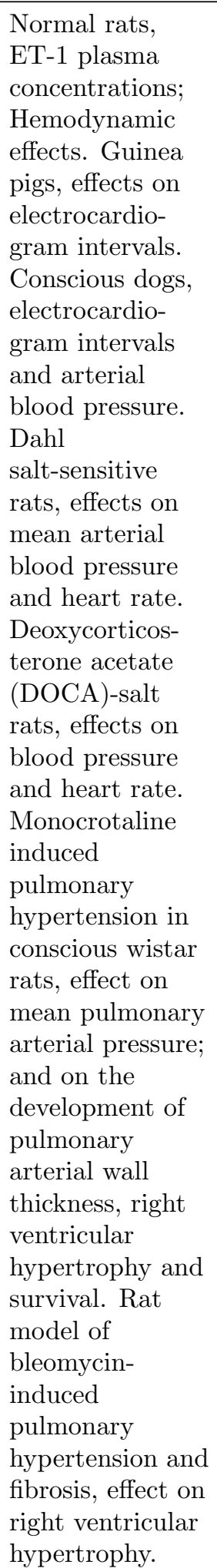 & $\begin{array}{l}\text { FDA reviews: } \\
\text { 204410Orig1s000 }\end{array}$ \\
\hline
\end{tabular}




\begin{tabular}{|c|c|c|c|c|c|}
\hline Drug & $\begin{array}{l}\text { approval- } \\
\text { date }\end{array}$ & Target & $\begin{array}{l}\text { In vitro } \\
\text { studies }\end{array}$ & $\begin{array}{l}\text { In vivo } \\
\text { studies }\end{array}$ & Reference \\
\hline Tolvaptan & 2009 & $\mathrm{~V} 2 \mathrm{R}$ & $\begin{array}{l}\text { Human } \\
\text { endocervical } \\
\text { carcinoma cell } \\
\text { line (Hela cells) } \\
\text { expressing } \\
\text { human AVP } \\
\text { receptor } \\
\text { subtypes, } \\
\text { antagonistic } \\
\text { effects. Hela } \\
\text { cells expressing } \\
\text { human AVP } \\
\text { V2-receptor, } \\
\text { antagonistic } \\
\text { effects. }\end{array}$ & 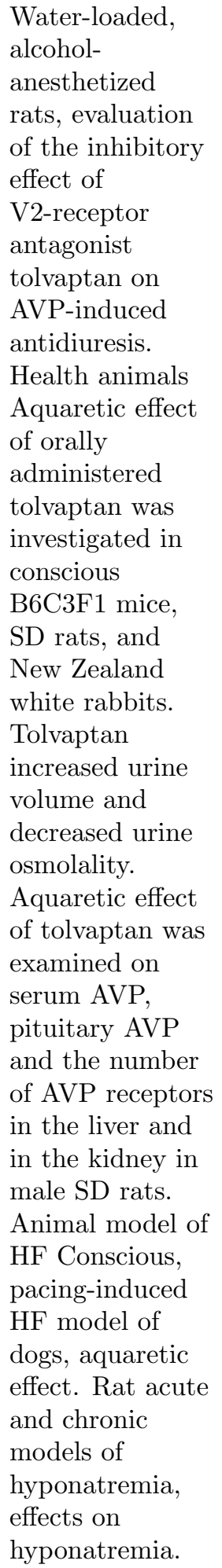 & $\begin{array}{l}\text { FDA reviews: } \\
\text { NDA } 22-275\end{array}$ \\
\hline
\end{tabular}




Drug

approval-
date

Ivabradine

2005

Hydrochloride

Target
HCN channels

In vitro
studies
Rat isolated
atria and aorta,
effect on the
spontaneous
beating rate;
Spontaneous
firing rate
(action
potentials per

In vivo

studies

Reference

Conscious

FDA reviews:

normotensive

206143Orig1s000

rat, Bradycardic

effect. Conscious

Long Evans rats,

Cardiac and

regional

haemodynamic

effects, including

min). Rabbit

isolated

sinoatrial node

tissue / cell,

Spontaneous

heart rate, mean

blood pressure,

cardiac index,

Stroke index,

Peak aortic flow,

firing rate

(action

$\mathrm{dF} / \mathrm{dt}_{\text {maz }}$, Total

peripheral

potentials per

conductance,

min); electrical

Central venous

activity;

pressure.

hyperpolarization-

activated $\left(\mathrm{I}_{\mathrm{f}}\right)$,

delayed-rectifier

potassium $\left(\mathrm{I}_{\mathrm{K}}\right)$,

T- and L-type

calcium $\left(\mathrm{I}_{\mathrm{Ca}, \mathrm{L}}\right.$

and $\mathrm{I}_{\mathrm{Ca}, \mathrm{T}}$ ).

Human atrial

myocyte, $\mathrm{I}_{\mathrm{f}}$

current. $\mathrm{HCN}$

channel isoforms

expressed in

HEK293 cells,

effect on HCN1

and $\mathrm{HCN} 4$

channels

including voltage

or currentdepen-

dency,

reversibility of

the interaction,

interaction with

open and/or

closed channel.

pigs,

Hemodynamic

and electrocar-

diographic

effects, The

effects on heart

rate, $\mathrm{LVdP} / \mathrm{dt}$,

cardiac output,

stroke volume

and total

peripheral

resistance. Rat

model of left

ventricular

dysfunction and

chronic HF,

myocardial

infarction was

induced by left

coronary artery

ligation. Dog

CHF model,

intracoronary

microemboliza-

tions, left

ventricular end

systolic volume,

left ventricular

ejection fraction.

132-AR

transgenic mice, effect on survival and on the development of HF. Rats

pressure

overload-induced 


\begin{tabular}{lllll}
\hline & $\begin{array}{l}\text { approval- } \\
\text { date }\end{array}$ & Target & $\begin{array}{l}\text { In vitro } \\
\text { studies }\end{array}$ & $\begin{array}{l}\text { In vivo } \\
\text { studies }\end{array}$ \\
\hline
\end{tabular}

